\title{
"Medicine of the Grassroots": Korean Herbal Medicine Industry and Consumption during the Japanese Colonial Period
}

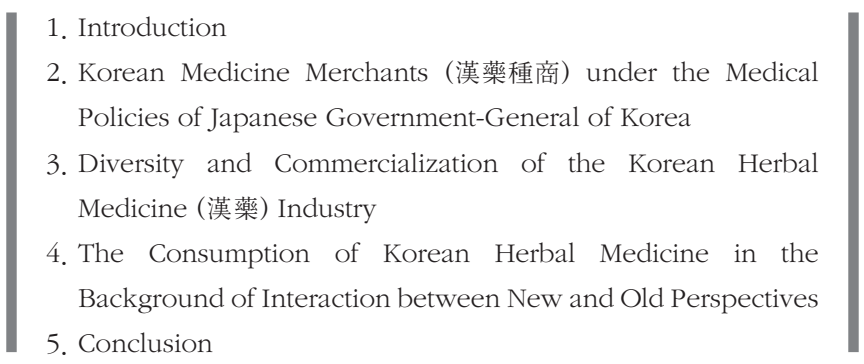

\section{Introduction}

A report titled "Old and New" published on January 18, 1932 in Maeil sinbo (每日申報, Korean Daily News) included an illustration "Hospital and Korean Herbal Store (漢藥房)"; it stated: “Western medicine and traditional Korean medicine (漢醫學), when considered from the perspective of architecture, present a contrast between new and old, west and east. While the influence of traditional Korean medicine is gradually decreasing, Western medicine, which is a product of the changing times, is gaining ground."

\footnotetext{
* Assistant Professor, East Asian Medical History, Korean Department \& Center for East Asian Studies, Sun Yat-sen University, China / E-mail: ahuang412@sina.com
} 
HUANG Yong-yuan : "Medicine of the Grassroots" : Korean Herbal Medicine Industry and Consumption during the Japanese Colonial Period

Figure 1. Hospital and Korean Herbal Store

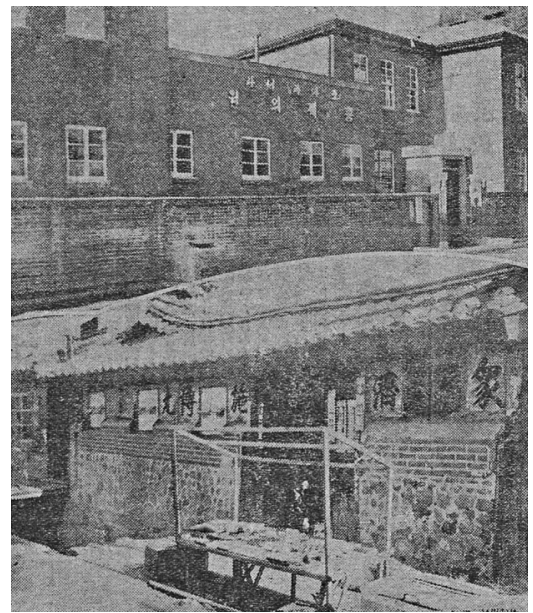

(“Old and New 新舊對照,” Maeil sinbo 每日申報, January 18, 1932)

After modern hospitals established medical authority, a new system of disease classification gained popularity. Compared with these hospitals, the traditional herbal store was a squalid and dingy Hanog (a traditional Korean house) that also doubled up as its owner's residence. Thus, it is easy to draw a conclusion about the "advanced" Western medicine and "backward" traditional Korean medicine. Moreover, due to the restrictions imposed by the colonial authorities on the latter, the number of Uisaengs (醫生, traditional Korean medicine doctors) started decreasing annually, severely affecting the field's status. However, this unilinear Darwinian narrative of medical modernization, overstated by the modern media, conceals the fact that, during the Japanese colonial period (hereafter "colonial period"), though traditional Korean medicine faced hurdles, it remained the primary and preferred form of treatment for specific conditions for a majority of Koreans. Undoubtedly, this fact is an irony 
HUANG Yong-yuan : "Medicine of the Grassroots" : Korean Herbal Medicine Industry and

Consumption during the Japanese Colonial Period

and challenges the narrative of medical modernization constructed only on the history of the popularization and development of Western medicine.

This paper examines the Korean herbal medicine (漢藥) industry to further explain this observation. Previous studies on traditional Korean medicine during the colonial period, contrasted against Korean herbal medicine, mainly focused on the Uisaeng. ${ }^{1)}$ I believe that the downsizing and waning influence of the Uisaeng compared with Western medicine during the colonial period cannot demonstrate the decline of traditional Korean medicine within the medical industry. In fact, there was a large and active group of Korean medicine merchants (hereafter "merchants") during the colonial period, and the production, circulation, and consumption of Korean herbal medicines were widespread. So far, research ${ }^{2}$ on Korean herbal medicine is limited to the Daegu Herbal Medicine Market (Daegu Yangnyeongsi [大邱藥令市], hereafter “Daegu Market”) (Choe, 1975; Kwon, 1986), or partially focused on the manufacture and sale of patent medicines (賣藥), a recent change in the field (Yang, 2006: 186-206; Park Y., 2013: 239-265; Suh, 2017: 104-136). ${ }^{3)}$ These studies have failed to

1) Studies on the Uisaeng are mainly divided into research on Uisaeng policies by the Government-General, and representative Uisaengs and medical books and associations. Representative research includes Shin C., 1990; Shin D., 2002: 333-370; 2003: 110-128; Park Y., 2008: 75-86; Kim N., 2006: 77-106; Kim N., 2011; Kim T. W., 2018: 75-101; Park J., 2016: 157-185; Huang, 2017: 169-198; Huang, 2018; Oh, 2019: 427-468.

2) Hong Hyeon-o's book (Hong, 1972) systematically presents the panorama of the Korean pharmaceutical history and lays a strong foundation for subsequent studies. However, it can hardly be considered a study in strict terms because it does not mark out the source of references. A recent study by Park Chan-young (2019) discusses the pharmaceutical policies by the colonial authorities and reactions of Korean practitioners from 1906 to 1938. However, it does not clearly define the differences between the practitioners of Western medicine and traditional Korean medicine, thus failing to profoundly reveal the development process of the Korean herbal medicine industry itself.

3) These researches are of great significance with respect to revealing the modern changes 
HUANG Yong-yuan : "Medicine of the Grassroots" : Korean Herbal Medicine Industry and Consumption during the Japanese Colonial Period

present the complete picture of Korean herbal medicine at that time, especially given the absence of details regarding its consumption and distribution. ${ }^{4)}$

Therefore, this paper, on the basis of previous research, attempts to comprehensively examine the condition of the Korean herbal medicine industry at that time from three perspectives: the policies introduced by the Japanese Government-General of Korea (hereafter "the Government-General"), changes implemented by the industry itself, and the consumption of these medicines. By examining these factors, I will deconstruct the biased narrative of medical modernization, which unilaterally emphasized the popularization and development of Western medicine, and reveal the inertia as well as ability of Korean traditions to act according to the circumstances during the colonial period; thus, this paper presents a medical ecosystem of coexistence, competition, and even interaction between western and traditional medicine during the modern transformation from the perspective of material culture. Ultimately, I hope that the research can help us reflect the writing paradigm of modern medical history and understanding of colonial modernization.

\section{Korean Medicine Merchants (漢藥種商) under the Medical}

in traditional Korean herbal stores, but they have almost ignored the fact that the manufacture and sale of patent medicines are only part of their business. In fact, in addition to patent medicine, the sale and circulation of traditional Korean medicinal herbs and decoctions still occupied the mainstream.

4) From this point of view, Lee Geod-me's research (2006: 227-236) was very creative. By quoting certain investigative reports, advertisements, newspapers, and literary works, the article presented the reality that the public relied more on herbal medicine than western due to economic, geographical, and habitual reasons. 
HUANG Yong-yuan : "Medicine of the Grassroots" : Korean Herbal Medicine Industry and Consumption during the Japanese Colonial Period

\section{Policies of Japanese Government-General of Korea}

The Government-General imposed stringent restrictions on the issuance of Uisaeng licenses, expiration dates, and places of practice through the Regulation of Uisaeng (醫生規則) issued in 1913 and subsequent amendments. ${ }^{5)}$ In contrast, it adopted a relatively lenient management policy vis-à-vis the merchants-this policy's basic principle was separating dispensation from prescription. ${ }^{\circ}$ In 1912, the Government-General followed the Japanese law (1887) to enact and issue the "Pharmaceuticals and Pharmaceutical Business Ban (藥品及藥 品營業管理令).”) Under the decree, relevant pharmaceutical practitioners

5) In November 1913, the Government-General issued "The Regulation of Uisaeng," based on which, the colonial authorities granted permanent licenses to traditional medicine practitioners who have previously practiced medicine. According to the regulation, subsequent applicants could only receive a five-year license (reduced to three after 1921), and in 1916, the colonial authorities implemented the Uisaeng exam system for those who applied for this license. Since the exam did not test the Uisaeng's original profession-knowledge of traditional Korean medicine-but only the knowledge of Western medicine, it was very difficult for applicants to clear it. Moreover, starting from July 1916, the colonial authorities required people who applied for the license to practice medicine in remote places such as mountainous areas. In December 1921, they passed the modified version of "The Regulation of Uisaeng," which limited Uisaengs' working area from province (道, do) to township (面, myeon). In other words, the license included time as well as space restrictions. For the related policy of the Government-General on Uisaengs, refer to Huang, 2018: 65-94.

6) Although the Japanese government had issued “Isei” (醫制) in 1874 and established the course of separation of dispensation from prescription, owing to the lack of pharmacists and a strong protest from the doctors, it finally permitted doctors to merely dispense to patients based on their own diagnoses - that is, the policy ends with an incomplete separation of dispensation from prescription (Medical Bureau of the Ministry of Health and Welfare, 1976: 35). In Korea, during the Chosun dynasty (朝鮮時 代), although traditional Korean medicine established the segregation between doctors who diagnosed and prescribed and drug sellers who sold Korean herbal medicines, the difference between them remained unclear (Shin D., 2002: 354; "The Medical Situation of Chosun 朝鮮國醫事景況," Iji shinbun 醫事新聞 74, 1883, p. 25).

7) “Yagpum chwiche gyuchig 藥品取締規則,” Maeil sinbo, September 23, 1911; “Yagpum chwiche gyuchig 藥品取締規則,” Maeil sinbo, September 26, 1911; “Chongdogbu gongmun 
HUANG Yong-yuan : "Medicine of the Grassroots" : Korean Herbal Medicine Industry and Consumption during the Japanese Colonial Period

were classified into four categories: pharmacists (dispensing medicines according to doctors' prescription, 藥劑師), drug sellers (selling drugs, 藥種商), drug manufacturers (making and selling drugs, 製藥者), and patent medicine sellers (making, importing, or selling patent medicines, 賣藥業者) (Shiroishi Hosei, 1918: 102-110). Simultaneously, the colonial authorities issued "Regulations for Pharmaceutical Inspection (藥品巡視 規則)” in July 1913, enforcing the management of the medicine market. ${ }^{8)}$ However, given that the aforementioned decrees were based on western medical standards, they could not be applied to the Korean herbal medicine field, irrespective of the division of related practitioners or the objects of drug management.

Consequently, from June 1912 to July 1916, the Government-General passed a series of administrative orders to regulate the merchants, ${ }^{9}$ under which, they were referred to as those who sell Korean herbal medicines in a specific province only after receiving a permit from provincial governors. Following this, traditional Korean medicine practitioners were clearly differentiated as Uisaengs and merchants. Furthermore, the colonial authorities also implemented the functional division of medicine

(總督府公文 Official Documents of the Governor's Office, Regulation No. 22) Yagpum geub yagpum yeongeob chwichelyeong (藥品及藥品營業取締令, Pharmaceuticals and Pharmaceutical Business Ban)," Maeil sinbo, April 25, 1912.

8) “Yagpum sunsi gyuchig 藥品巡視規則,” Chosunchondokbugwanbo 朝鮮總督府官報 288, July 16, 1913.

9) “Matters Related to Chemical Management 藥品取締二關スル件”, Gyeongmuhwibo 警 務彙報 June 27, 1912, pp. 58-59; “Document about Korean Medicine Management 漢 藥ノ取締二關スル件,” Gyeongmuhwibo July 28, 1912, pp. 21-22; “Document on the Management of Pharmacists 藥種商取締二關スル件, ” Pyeongannam-do Gyeongmubu Compilation 平安南道警務部編纂, Wisaeng gyeongchal gangui ilban (衛生警察講義一斑, Hygienic Police Instructor) (Pyeongannam-do Gyeongmubu, 1913), p. 302; "Document about Korean Medicine Management 漢藥取締二關スル件, ”Gyeongmuhwibo 121, June 1916, pp. 20-21; "Document of the Preparation of Korean Medicine Merchants 朝鮮人藥 種商調劑二關スル件, Gyeongmuhwibo 124, July 1916, p. 131. 
HUANG Yong-yuan : "Medicine of the Grassroots" : Korean Herbal Medicine Industry and Consumption during the Japanese Colonial Period

dispensation rights between doctors and pharmacists, and specified that the Uisaengs could only dispense herbal medicine to his/her own patients, while the merchants were allowed to dispense by prescription (Haenimseowon compilation, 1938: 2) ${ }^{10)}$ However, as far as a specific herbal medicine being sold was concerned, such sale enjoyed complete freedom, because, barring a few highly toxic drugs, the herbal medicines were different from their western counterparts and lacked the regulation of pharmacopoeia. ${ }^{11)}$

Since the merchants were different from the Uisaengs and not regarded as medical professionals, it was easier to acquire the permit for selling medicinal herbs than the Uisaeng license. Initially, the merchants could obtain the permit through applications, but later, an exam system was enacted in 1923. ${ }^{12)}$ However, despite its implementation, until the 1930s, test scores were not the key criteria for issuing the permit, and questions were based on traditional herbal knowledge. Thus, the qualification test for the merchants was easier than that for the Uisaengs or Western medicine apothecaries (洋藥種商). Moreover, unlike the Uisaeng license, the permit was valid for life. In addition, from the perspective of nationality, both Japanese and Koreans were involved in Western medicine apothecaries,

10) The prescription of traditional Korean medicine is generally based on its theories and the principle of Gunsinjwasa (君臣佐使) (a prescription should include the Gun [君, sovereign], Sin [臣, minister], Jwa [佐, assistant], and Sa [使, messenger] ingredient drugs), which mixes several kinds of medicinal materials to form a compound [複方] (there are also a few simple recipes [單方]). A medicinal herb that is separate, isolated, and not prescribed is called a wholesale medicinal herb (乾材).

11) "Document on the Preparation of Drugs by Korean Medicine Merchants," Gyeongmuhwibo 124, July 1916, p. 131.

12) Shiroishi, 1918: 106; "The Drugstore Also Has a Test System, If You Fail the Exam, You Cannot Even Run a Pharmacy 藥局도 試驗制, 시험에 락뎨하면 약국도 못해먹어,” Dong-a ilbo, April 15, 1923. 
HUANG Yong-yuan : "Medicine of the Grassroots" : Korean Herbal Medicine Industry and Consumption during the Japanese Colonial Period

while the occupation of medicine merchant was practiced only by Koreans. Hence, compared with other industries, Koreans were much more dominant in the Korean herbal medicine industry. This made the medicine merchant more accessible and appealing to the Korean society at that time.

Unlike the continuous decline in the number of Uisaengs, from 5,800 in 1914 to 3,300 in 1944, the merchants' number did not decrease (Huang, 2018: 85-86) - it increased from over 7,000 in 1914 to more than 10,000 in the early 1920s. Although the number showed a tendency to decrease gradually subsequently, it remained at over 7,000 until the final phase of the colonial period. 
HUANG Yong-yuan : "Medicine of the Grassroots" : Korean Herbal Medicine Industry and Consumption during the Japanese Colonial Period

Figure 2. Change in Number of Korean Drug Sellers (Korean Medicine Merchants) during the Japanese Colonial Period ${ }^{13)}$

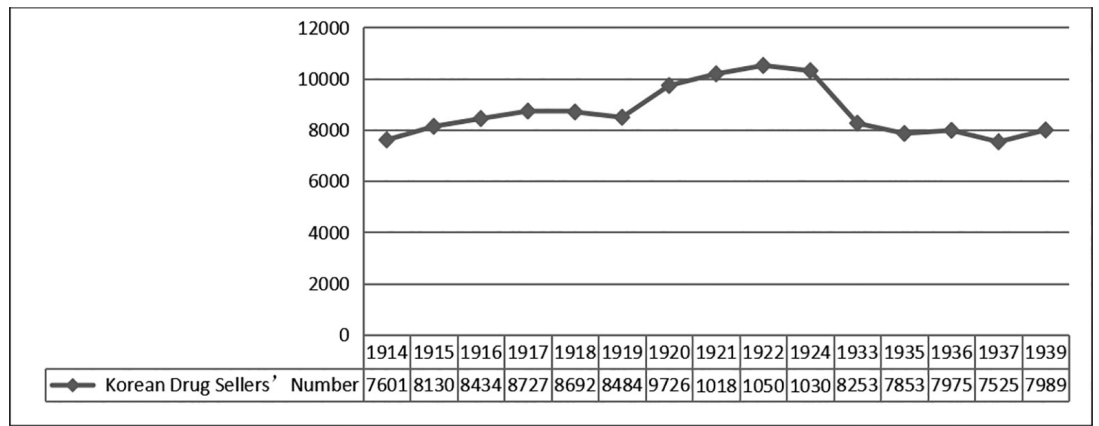

As we can see from the horizontal line, the merchants made up the largest group among practitioners in the entire medical industry. During the colonial period, Western medicine practitioners, including pharmacists and apothecaries, also increased gradually, but by 1942 ,

13) Continuous statistics on the number of merchants during the colonial period were not available. Data in the 1910s and 1920s was based on the calculations in the Statistical Yearbook of the Government of Colonial Korea. Since this data included a small number of Western medicine apothecaries, it is not completely consistent with the number of merchants. However, as Shin Dong-won (2002: 359) argued, except a few hundreds, all were merchants. Therefore, these values can reflect the merchants' approximate numbers. After 1925, the number of these merchants was not available because the Statistical Yearbook of the Government of Colonial Korea only counted the Western medicine apothecaries. In contrast, data from the 1930s shows the exact number of the merchants, based on the following information: “Statistic Table of Medical Institutions (the end of 1933)," Kawaguchi Riichi 川口利 一, “The Document on the Promotion of Herbal Cultivation 藥草栽培獎勵に關する問 題," Gyeongmuhwibo, July 1934, p. 44; “A Comparison Table Between Population and Drug Dealers in Each Province (the end of 1935) 各道別人口と藥品營業者比較 表,” Gyeonggi Provincial Hygiene Department ed., Sanitary Outline 衛生概要, 1937, p. 207; Gyeongmubu wisaenggwa (警務局衛生課), “The Table of Drug Seller (the end of December 1936) 藥品營業者表(1936年12月末), Explanation data for the 73th Imperial Council, 1937, National Archives of Korea, CJA0002471; "The Table of Drug Seller (the end of December 1937), ” Chosun yaghaghoe jabji 朝鮮藥學會雜誌 18-3, June 1938, p. 21; "Declaration on the Establishment of Oriental Medicine Association 東洋醫藥協會創立趣旨書, ” Oriental Medicine 東洋醫藥, July 1, 1939, p. 10. 
HUANG Yong-yuan : "Medicine of the Grassroots" : Korean Herbal Medicine Industry and Consumption during the Japanese Colonial Period

their number leveled at 2,000, which was less than one-third of the merchants. Even the number of all Uisaengs and Uisas (醫師, Western medicine doctors) combined was lower than that of the merchants. Simultaneously, unlike Western medicine doctors, pharmacists, and Western medicine apothecaries concentrated in Kyungsung (京城) and other cities, the merchants had an extensive presence in each gun (郡) (Gyeonggi-do wisaenggwa ed., 1937: 203). Moreover, barring a small number of Chinese, all other merchants were Koreans, so they naturally had a greater affinity toward the Korean society. In some rural areas in particular, there were very few doctors; hence, the merchants' role was even more significant, as indicated by, for example, a survey of 61 rural families in Chungcheongnam-do (忠清南道), Dangjin-gun (唐津郡), Songak-myeon (松获面), and Ogogli (梧谷里) in 1939.

As Table 1 shows, there was one Western medicine doctor and Uisaeng each in Songak-myeon. However, since the Western medicine doctor lived far from Ogokri village, and the treatment charge was high, the villagers found it unaffordable. Among the 66 treatments the Western medicine doctor offered, 63 were free; in contrast, traditional Korean medicine practitioners including the Uisaengs and merchants totaled 200. Among them, most villagers took treatment from the merchants (Bang San-yeol, Ibid., p. 44); specifically in the countryside, except folk therapy, patent medicine, and superstitious treatments, if people opted for medical institutions, the Korean herbal store was the most obvious choice. 
HUANG Yong-yuan : "Medicine of the Grassroots" : Korean Herbal Medicine Industry and Consumption during the Japanese Colonial Period

Table 1. Current Situation of Medical Institutions in Songak-myeon (1939)

\begin{tabular}{c|c|c|c|c|c}
\hline $\begin{array}{r}\text { Medical } \\
\text { Institution }\end{array}$ & $\begin{array}{c}\text { Western } \\
\text { Medicine } \\
\text { Doctor }\end{array}$ & Uisaeng & $\begin{array}{c}\text { Korean } \\
\text { Medicine } \\
\text { Merchant }\end{array}$ & $\begin{array}{c}\text { Patent } \\
\text { Medicine } \\
\text { Seller }\end{array}$ & $\begin{array}{c}\text { Patent } \\
\text { Medicine } \\
\text { Peddler }\end{array}$ \\
\hline Japanese & 0 & 0 & 0 & 0 & 0 \\
\hline Korean & 1 & 1 & 3 & 6 & 3 \\
\hline
\end{tabular}

(Bang San-yeol 方山烈, “The Actual Condition of a Rural Area Based on Lifestyle and Health 生活樣式 及び保健上より見た一農村の實況,” Chosunchongdogbu josa wolbo 朝鮮總督府調查月報, January 1942, p. 44)

Table 2. A Survey of the Utilization of Medical Treatment by Rural Families in Songakmyeon Ogokri (1938)

\begin{tabular}{l|c|c|c|c|c|c|c}
\hline $\begin{array}{r}\text { Medical } \\
\text { Method }\end{array}$ & $\begin{array}{c}\text { Western } \\
\text { Medicine } \\
\text { Doctor }\end{array}$ & $\begin{array}{c}\text { Traditional } \\
\text { Korean } \\
\text { Medicine } \\
\text { Practitioner } \\
\text { (漢方醫) }\end{array}$ & $\begin{array}{c}\text { Patent } \\
\text { Medicine }\end{array}$ & $\begin{array}{c}\text { Herbal } \\
\text { Medicine } \\
\text { (草木) }\end{array}$ & $\begin{array}{r}\text { No } \\
\text { Treatment }\end{array}$ & $\begin{array}{c}\text { Super- } \\
\text { stition }\end{array}$ & Total \\
\hline Times & 66 & 200 & 153 & 187 & 150 & 30 & 786 \\
\hline Percentage & 8.4 & 25.4 & 19.4 & 23.9 & 19.0 & 3.9 & 100 \\
\hline Note & \multicolumn{3}{|c|}{33.8} & \multicolumn{6}{|c|}{66.2} & & 100 \\
\hline
\end{tabular}

(Bang San-yeol, Ibid., p. 47)

Effectively, the aforementioned survey referred to Uisaengs as "traditional Korean medicine practitioners with a license (免許漢方醫), ” and designated part of the merchants who had excellent medical skills as “old traditional Korean medicine practitioners (老漢方醫)” or “traditional Korean medicine practitioners who sell Korean herbal medicine (藥 種商漢方醫).” This partially reflected that, at actual medical sites, the division between Uisaengs and merchants was not always apparent, primarily because of the difficulty in acquiring the Uisaeng license. Many who originally wanted to practice medicine ultimately chose to 
HUANG Yong-yuan : "Medicine of the Grassroots" : Korean Herbal Medicine Industry and Consumption during the Japanese Colonial Period

become merchants, or those who were merchants transitioned to become Uisaengs. ${ }^{14)}$ Moreover, at that time, many of the merchants not only sold Korean herbal medicines but also checked the patient's pulse and prescribed treatment, just like the Uisaengs did. ${ }^{15)}$ Conversely, although many acquired the Uisaeng license, they managed Korean herbal stores and treated patients simultaneously. ${ }^{16)}$ This indicated that, during the colonial period, Korean herbal stores were an important medium for the survival of the traditional Korean medicine lifeline, and were key to promoting the consumption of Korean herbal medicines.

During the colonial period, unlike the Uisaengs, the merchants faced fewer restrictions, and maintained a considerable presence. This, however, was not a result of the colonial authorities' intended action-similar to the Uisaengs, the Government-General had permitted the merchants' presence after taking into account Korean medical customs and the lack of personnel to administer Western medicines; the colonial authorities, who intended to wait for Western medicine's popularization and the phasing out of traditional Korean medicine, believed that the merchants would be replaced as the number of pharmacists increased (Gyeongmu chonggambu wisaenggwa 警務總監部衛生課, 1917: 302). Because the

14) "The Editorial Staff, Senior Needs to Educate Juniors 先進은 後進을 敎養이 必要," Chungnam Pharmaceutical Magazine 忠南醫藥, May 5, 1936, p. 34.

15) “Sin Tae-sik, a Gynecologist at Jesedang Herbal Store in Yeongju 婦人病 專攻榮州 濟世堂乾材藥局 申太湜氏, ” Dong-a ilbo, October 30, 1934; “An Introduction to New Kimpo: the Authority of Korean Herbal Medicine-Yun Byeongcho, the Owner of Ilsim-dang Herbal Store 新興金浦紹介版 漢藥界의 權威一心堂藥房 尹柄椒氏,” Dong-a ilbo, December 8, 1937.

16) "Free Provision of Korean Herbal Medicine Treatment: in Bohye Pharmacy in Gyonamdong Downtown 漢藥無料施療 : 市內橋南洞普惠藥房에서,” Dong-a ilbo, January 19, 1933; “A Medical Master: Yeongheung-dang Pharmacy Gang I-seong 刀圭界의 巨星 永 興堂藥局 姜而聲氏,” Dong-a ilbo, October 30, 1934. 
HUANG Yong-yuan : "Medicine of the Grassroots" : Korean Herbal Medicine Industry and Consumption during the Japanese Colonial Period

nature of work of the Uisaengs and merchants was intertwined, with the former providing prescription and the latter dispensing the medicine, as the number of Uisaengs decreased, so did the number of attached merchants. ${ }^{17)}$ In other words, the colonial authorities imposing restrictions on the Uisaengs and maintaining a relatively tolerant attitude toward the merchants was not an indication of their preference for the latter, only a temporary understanding. The "loophole" in the policy left a wide gap for the merchants to survive, and made it possible for them to eke out a livelihood, or even a fortune, by relying on the huge demand for Korean herbal medicine.

\section{Diversity and Commercialization of the Korean Herbal Medicine (漢藥) Industry}

During the colonial period, the Korean herbal medicine industry did not decline, but grew steadily in the backdrop of the gradual popularization of Western medicine and restrictions imposed by the authorities on the development of traditional Korean medicine. Apart from the existing medical demand, the industry's development can also be attributed to the merchants' response to the situation-they played a significant role in the circulation and commercialization of Korean herbal medicine. The circulation structure can be seen in the following figure.

As Figure 3 reveals, drugs circulated in the Korean market during that time were divided into imported drugs and Korean domestic drugs; all

17) Gang Hyeok 姜赫, "My Humble Opinion about Oriental Medicine Revitalization Policy at the Time of Its Publication 發刊에 臨하여 東洋醫藥復興策管見, ” Oriental Medicine 東 洋醫藥, July 1, 1939, p. 28; Hyun Ho-sub 玄鎬孌, “A Review of Oriental Medicine 漢醫 學의 再檢討,” Oriental Medicine, December 6, 1939, p. 16. 
HUANG Yong-yuan : "Medicine of the Grassroots" : Korean Herbal Medicine Industry and Consumption during the Japanese Colonial Period

would either enter the market through the merchants, or be available at local Korean medical clinics or hospitals, acquired from the herbal medicine markets in Daegu (大邱), Jeonju (全州), Daejeon (大田), etc. Either way, the merchants were the main source of the distribution and trade of Korean herbal medicine, and the central link connecting the market and consumer. Thus, their activities largely determined the market's direction in the colonial period.

Taking into consideration Korean medical traditions and society's needs, some merchants continued to sell traditional decoctions and drugs, and simultaneously made and sold patent medicines after obtaining sales permit from the authorities. They adapted easily to the changing times. Thus, traditional Korean herbal medicine embraced its diversity and moved toward commercialization and marketization. According to the divergent emphasis on the main business, market objectives, the owner's self-recognition, and public image, the Korean herbal medicine industry could be divided into three categories: traditional, mixed, and ginsengexclusive. The following section provides a general introduction on the characteristics and different types of Korean herbal stores. 
HUANG Yong-yuan : "Medicine of the Grassroots" : Korean Herbal Medicine Industry and Consumption during the Japanese Colonial Period

Figure 3. The Circulation Structure of Korean Herbal Medicine during the Japanese Colonial Period (before the Sino-Japanese War) ${ }^{18)}$

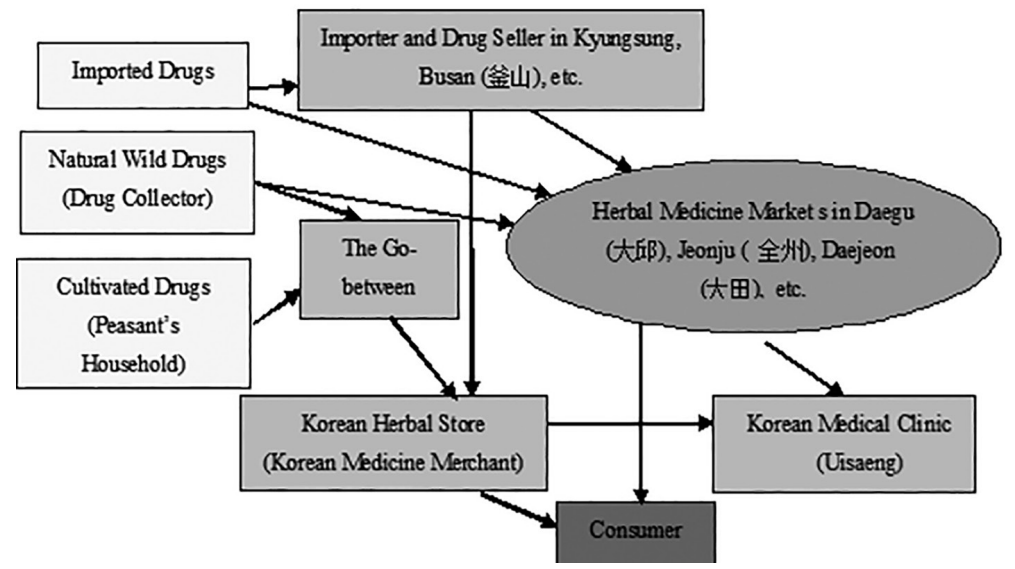

The traditional type refers to drugstores that exclusively or primarily sold Korean herbal medicines, including dried drugs, decoctions, traditional pills, ginseng, and velvet deer horn. Although an array of Western medicines had entered the Korean market by that time, the demand for herbal medicines did not drop sharply. In 1927, Kim Hak-chun (金學

18) Shidoya Tsutomu 石户谷勉, “Herbal Plants and Their Use, Produced in the Mountains and Hills of Chosun 朝鮮の山野より生產する藥料の植物と其利用,” Chosun and Manchuria 221, April 1926, pp. 37-38; Isidoya Seutomu, “The Herb of Chosun 朝鮮に 於ける藥草,” Chosun 302, July 1940, p. 58; “In Order to Ease the Difficulty of Buying Foreign-made Drugs, Herbal Medicine Importers Gathered and Formed a Union with

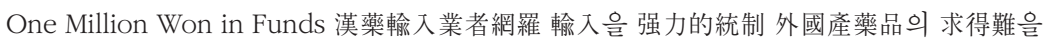
打破코저 資金百萬圓으로 組合結成,” Dong-a ilbo, August 12, 1939; Park C., 2017: 148. After the outbreak of the Sino-Japanese War, with the implementation of the General Mobilization System (總動員體制) and Controlled Economic Policy (統制經濟政策), Korea's pharmaceutical market had gradually established overall control, including production (imports), circulation, and consumption. Therefore, the circulation of herbal medicines during the War presented a different picture. 
HUANG Yong-yuan : "Medicine of the Grassroots" : Korean Herbal Medicine Industry and Consumption during the Japanese Colonial Period

春), the owner of Gongan-dang (共安堂) Drug Store in the Gyeonggido (京畿道) market in Anseong (安城), said, “Koreans have taken herbal medicine since ancient times, and although a lot of Western medicines have entered Korea presently, the sale of herbal medicine continues to increase steadily." ${ }^{19)}$ Thus, many Korean herbal stores continued their traditional business, and some even grew to become large.

For example, in Kyungsung, there was Hwanggeum-dang (黃金堂) that was operated by Yu Chi-ok (劉致玉), Yeongchang-dang (永昌堂) owned by Choe Seong-pil (崔聖倨), Gonghwa-dang (共和堂) run by Choe Heung-mo (崔興模), etc., and all these were concentrated around Donghyeon (銅峴), also called Hwanggeum-jung (黃金町) after 1914, now around Eulji-ro (乙支路) 1-7, which was called the "street of Korean herbal medicine." In areas beyond Kyungsung, there was Kim Hong-jo Yak-Bang (金弘祖藥房) in Daegu, Beopgyo-guk (法橋局) owned by Kim Soo-cheol (金壽哲) in Pyeongyang (平壤), Namil-dang (南一堂) run by Park Jae-sin (朴在新) in Ganggyeong (江景), Gwangchang-dang (廣昌堂) owned by Kim Nak-hyeon (金洛鉉) in Gongju (公州), Namchang-dang (南 昌堂) belonging to Kim Bong-du (金奉斗), Kim Chun-bae Yak-Bang (金 春培藥房) in Daejeon (大田), and Dongchun-dang (東春堂) owned by Sin Hak-gyun (申學均) in Busan (釜山). ${ }^{20)}$

19) "Biographies of Successful Businessmen (31): From a Drugstore Servant to a Korean Herbal Medicine Giant 事業成功者列傳 (三十一) 藥房의 使喚으로 漢藥界의 巨星, ” Dong-a ilbo, February 12, 1927.

20) Hwanggeumdang yagbo 黃金堂藥報 108, December 1936; “Special Advertisement: Choe Seong-pil Wholesale Medicinal Herb Store 特別廣告 崔聖咟 乾材藥局,” Daehan maeil sinbo, July 5, 1910; “Yeongchang-dang Pharmacy 永昌堂大藥房,” Maeil sinbo, June 19, 1914; “Yeongchang-dang Wholesale Medicinal Herb Store 永昌堂乾材藥局,” Dong-a ilbo, May 14, 1920; “The Wholesale Medicinal Herb Store, Choe Heung-mo 乾 材藥局 崔興模, ”Daehan maeil sinbo, August 26, 1910; “Beopgyo-guk (Pyeongyang) 法 橋局(平壤),” Dong-a IIbo, March 12, 1938; “Biographies of Successful Businessmen (7), 
HUANG Yong-yuan : "Medicine of the Grassroots" : Korean Herbal Medicine Industry and Consumption during the Japanese Colonial Period

Among these stores, Hwang Geum-dang in Kyungsung even opened a branch in Longing (龍井) in Northeast China, and the images of Yeongchang-dang and Gonghwa-dang below demonstrate their success. ${ }^{21)}$ Though the stores continued their traditional business, following the Japanese Annexation of Korea, they adopted novel methods such as advertisements and cash on delivery (代金引換), largely improving the distribution network. Among the owners, Choe Seong-pil of Yeongchang-dang was the first to make the Market Price List of various Korean medicinal herbs on a regular basis and deliver it to customers across the country. He promoted the sale of medicinal herbs, and largely encouraged price competition in the Korean herbal medicine industry. ${ }^{22}$

Building a Large Capital of Hundred Thousand Won After Starting as a Peddler 事業成 功者列傳 (七) 行商으로 着手하야 十餘萬圓 大資本,” Dong-a ilbo, January 7, 1927; “The Full View of Baekje's Ancient Capital—-Gongju, the Star of Korean Herbal Medicine, the Owner of Gwangchang-dang-Kim Nak-hyeon 百濟古都公州의 全貌 漢藥界에 名 星廣昌堂 金洛鉉氏,” Dong-a ilbo, May 22, 1938; “A Bulletin Board of Daejeon(1) 大田 案內版其一," Dong-a ilbo, July 7, 1931; “Large-scale Business Expansion, Dongchundang Pharmacy, Sin Hak-gyun 業務大擴允 東春堂大藥房 申學均氏,” Dong-a ilbo, December 11, 1935.

21) “Advertisement,” Dong-a ilbo, April 1, 1920; “Yeongchang-dang Pharmacy 永昌堂大藥 房," Maeil sinbo, June 19, 1914; “Gonghwa-dang Pharmacy 共和堂本鋪," Maeil sinbo, March 14, 1917.

22) “A General Meeting of Representatives of the Pharmaceutical Industry 藥業 總代의 悖行," Maeil sinbo, September 26, 1913; "Yeongchang-dang Pharmacy," Maeil sinbo, June 19, 1914. 
HUANG Yong-yuan : "Medicine of the Grassroots" : Korean Herbal Medicine Industry and Consumption during the Japanese Colonial Period

Figure 4. Yeongchang-dang (崔聖须乾材藥局, in Donghyeon)

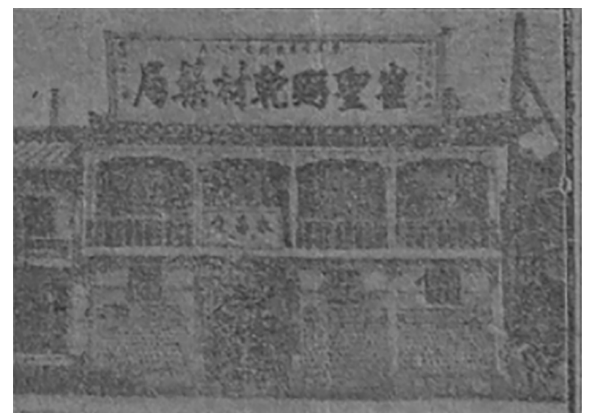

(“Yeongchang-dang Pharmacy 永昌堂大藥房,” Maeil sinbo, June 19, 1914)

Figure 5. Gonghwa-dang (崔興模乾材藥局, in Donghyeon)

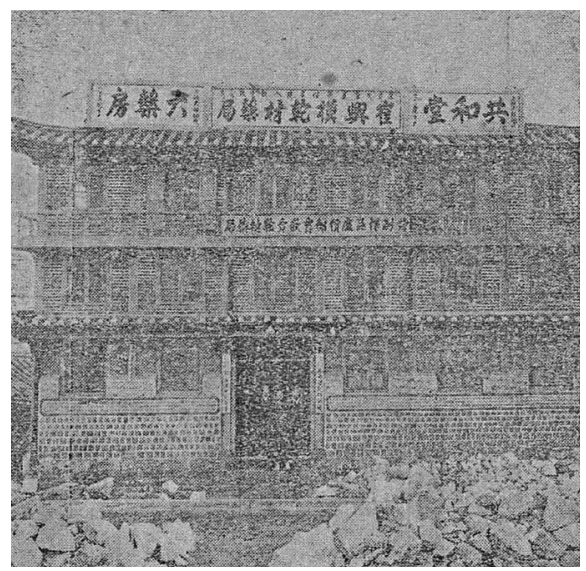

(“Gonghwa-dang Pharmacy 共和堂本鋪,” Maeil sinbo, March 14, 1917)

The sizes of the herbal medicine stores beyond Kyungsung were also considerable. For example, Kim Hong-jo Yak-Bang in Daegu Market was a giant in the herbal medicine industry at that time. Kim Hongjo (金弘祖) was born in Gaesong (開城) and arrived in Daegu in 1890. He took advantage of Gaesong's traders to engage in the business of ginseng, and in 1915, became a Korean medicine merchant. He not only 
HUANG Yong-yuan : "Medicine of the Grassroots" : Korean Herbal Medicine Industry and Consumption during the Japanese Colonial Period

valued credibility but also paid great attention to the quality of Korean medicinal herbs. Hence, he bought land in the area where the herbs were cultivated, leased it to peasants, and asked them to continue the cultivation as a pastime and provide the herbs to his store. He was also adept at hoarding for profiteering. When he believed the market to be profitable, he would buy medicinal herbs in huge quantities from across Korea; when the quantity of some herb was in excess, he would destroy it to maintain the price. Some people criticized him as "arbitrary" and "capitalizing on the market," but through his management skills, he made a giant leap, starting with 3,000-4,000 won to as much as over 100,000, becoming a tycoon in the 1930s (Park G., 2011: 84-85).

Another case in point is Namil-dang at the Ha-market (下市場) of Kang Kyung-eup (江景邑) on Chungcheongnam-do (忠清南道) in the 1920s. At that time, it was widely known as the largest Korean herbal store outside Namdaemun (南大門) (Institute of Urban Architecture, 2013: 26). ${ }^{23)}$ The honorable family of Myeongjae (明齋宗家, Yun Jeong 尹拯) of Papyeong Yun (坡平尹氏) in No Seong-myeon (魯城面) of Nonsan-gun (論山郡) was among its major customers. Though the family lived $20 \mathrm{~km}$ away from the store, they often bought a huge quantity of Korean herbal medicines from it (Figure 6).

23) The original owner of Namil-dang was Kang Deok-geun (姜德根); it was later taken over by his son, Kang Jae-won (姜在元). In 1932, when Namil-dang became a joint venture, the corporate representative was Park Jae-sin (朴在新). Around 1934, the store's name was changed from Namil-dang to Suseong-dang (壽星堂), whose owner was Ho Sun-seong (扈淳聖). 
HUANG Yong-yuan : "Medicine of the Grassroots" : Korean Herbal Medicine Industry and Consumption during the Japanese Colonial Period

Figure 6. The Transaction Receipt between the Family of Papyeong Yun in No Seong-myeon and Namil-dang ${ }^{24)}$

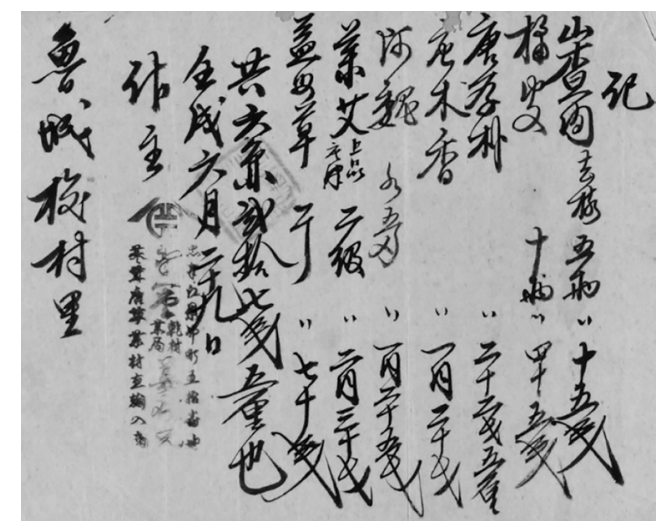

Compared with the traditional stores that continued their business in traditional herbal medicine, the mixed type ones not only sold general Korean herbal medicines but also actively jumped into manufacturing and selling patent medicines. With the arrival of Western medicine and Japanese drug sellers after the opening of the port, the traditional medicine market began to change. Some merchants enthusiastically reacted to the changing situation and looked for new avenues, including entering the patent medicine market (Yang, 2012: 237). In addition to traditional Korean pills, plasters, and powders, they borrowed western pharmaceutical skills to make patent medicines (Yang, 2012: 238). Compared with traditional decoctions, the intake of patent medicines was definitely easier for people. It also aided the commercialization of

24) “The Transaction Receipt between the Family of Papyeong Yun (坡平尹氏, No Seongmyeon, Nonsan-gun) and Namil-dang (南一堂),” June 29, 1922. http://archive. aks. ac. kr/Inspection/insDirView. aspx?dataUCI=G002+AKS+KSMXD.0000.0000-20101008.B004a_004_01777_XXX. Accessed December 12, 2019. 
HUANG Yong-yuan : "Medicine of the Grassroots" : Korean Herbal Medicine Industry and Consumption during the Japanese Colonial Period

herbal medicine and boosted the profits of herbal stores.

Meanwhile, Lee Hui-seon (李熙善), the owner of Changsang-dang (蒼生 堂) in Gyeonggi-do (京畿道), Anseong-si (安城市), replicated the liquid preparation of Western medicine to produce the so-called Jeonggi $\mathrm{Su}$ (精氣水) that is based on the well-known Korean Six-Ingredient Decoction (六味湯), Eight-Ingredient Decoction (八味湯), and Perfect Major Supplementation Decoction (十全大補湯). He also advertised that compared with traditional drugs, Jeonggi Su is "portable, easy to digest, and fast-acting. ${ }^{25)}$ These patent medicines were different from traditional ones in appearance, but the ingredients were essentially similar. Thus, they can be regarded as Korean herbal medicines in a broad sense. ${ }^{26}$ During the colonial period, the western pharmaceutical industry in Korea was still underdeveloped until the 1930s, and before the 1920s, the import and sale of Western medicines were almost solely controlled by Japanese pharmacies (Hong, 1972: 65). Hence, one important characteristic of the Korean herbal medicine industry was using Korean medicinal herbs as the main raw materials to manufacture and sell patent medicines. ${ }^{27)}$

From the end of the Great Han Empire to the early colonial period, many traditional Korean herbal stores entered the patent medicine market, including major ones such as Cheon-il Yak-Bang (天一藥房, 1913) of Jo In-seop (趙寅狺), Hwapyeong-dang (和平堂, 1894) of Lee Eung-seon (李應善), Donghwa Yak-Bang (同和藥房, 1897) of Min Byeong-ho (閔並

25) “Yukmi Jeonggi Su 六味精氣水,” Dong-a ilbo, April 2, 1923.

26) “Donghwa Pharmacy Advertisement 同和藥房廣告,” Daehan maeil sinbo, July 22, 1909; “Donghwa Pharmacy Advertisement 同和藥房廣告," Daehan maeil sinbo, January 6, 1910.

27) Hong Hyeon-o believed the patent medicine market in the southern part of the Korean Peninsula was dominated by the Japanese, while the northwest was dominated by Koreans (Hong, 1972: 4). 
HUANG Yong-yuan : "Medicine of the Grassroots" : Korean Herbal Medicine Industry and Consumption during the Japanese Colonial Period

浩), and Chosun Maeyak Corporation（朝鮮賣藥株式會社, 1913） of Lee Seok-mo (李碩謨). They began making and selling patent medicines and even brought out their flagship ones, such as Jo Go-yak (趙膏藥, a drug to heal sores) and Cheon-il Ryeongsin-hwan (天一靈神丸, a digestive) of Cheon-il Yak-Bang, Palbo-dan (八寶丹, a digestive), Taeyang jogyeonghwan (胎養調經丸, a gynecological drug), and Ja Yang-hwan（滋陽丸, an invigorator) of Hwapyeong-dang, and hwal Myeong-su (活命水, a drug to relieve indigestion) of Donghwa Yak-Bang. These were popular throughout Korea.

The manufacture and sale of patent medicines using Korean medicinal herbs as raw materials became the most important opportunity for the commercialization of Korean herbal stores, and aided their transition from traditional to modern pharmacies, and even pharmaceutical companies. Facing fierce competition in the patent medicine market, major Korean herbal stores actively took to modern marketing and management methods of trademark registration, advertising, promotion, remittance settlement, and the establishment of branches and agents, which advanced the transformation of the traditional Korean herbal medicine industry tremendously (Yang, 2006: 198, 203-205; Suh, 2017: 114-126).

In the 1880s, Jo Geun-chang (趙根䢞), ${ }^{28)}$ father of the founder Jo Inseop of Cheon-il Yak-Bang, was a Korean medical doctor and ran a small herbal store in the Yeji-dong (禮智洞) neighborhood of Kyungsung. With the sore healing drug handed down by his forefathers 150 years ago, he cured many patients who had undergone surgery. Jo In-seop (1891-?) graduated from a well-known private school called Whimoon

28) After the Japanese Annexation of Korea, he obtained the Uisaeng license in 1914 (“Uisaeng myeonheo 醫生免許,” Chosunchongdogbu gwanbo, October 2, 1914). 
HUANG Yong-yuan : "Medicine of the Grassroots" : Korean Herbal Medicine Industry and Consumption during the Japanese Colonial Period

School (徽文義塾) in 1910 and went to Japan for further studies. When he returned, he inherited the store, and formally established Cheon-il YakBang in 1913. While Cheon-il Yak-Bang was conducting its business in traditional Korean herbal medicine, Jo In-seop used his forefathers' drug to make the patent medicine "Jo Go-yak," which became popular across the Korean Peninsula. Cheon-il Yak-Bang capitalized on the brand's popularity to enter the patent medicine market. ${ }^{29)}$ Relying on the effect of "Jo Go-yak" and Jo In-seop's excellent management skills, Cheon-il Yak-Bang became a large-scale operator in the 1930s-until 1938, it had a registered capital of over 300,000 won, and annual sales reached about 1.3 million won. Jo In-seop also owned Cheon-il Pharmacy Corporation, whose registered capital was 500,000 won. Apart from the main shop in Yeji-jeong (禮智町) in Kyungsung, Cheon-il Yak-Bang branches were set up in Hwanggeum-jeong in Kyungsung, and in Daegu, Pyeongyang, Gwangju (光州), and Cheonan (天安). Additionally, there were dozens of agent shops, and more than 1,000 franchises. There were 210 staffers in the main shop, and 50 in branches. The annual net income was about 210,000 won. After deducting the operating costs, bank interest, etc., annual profit rose to about 60,000 won. The family's personal property and real estate, on the other hand, was valued at more than 500,000 won. ${ }^{30)}$

29) "Managed with Hardship for 150 years, 'Jo Go-yak,' the King of Pharmaceutical Industry 勤勤孜孜百五十年 藥業界王座 “趙膏藥”, Chosun ilbo 朝鮮日報, January 4, 1936; “The Grand Vision of Medical Industry in the Korean Peninsula 牛島醫藥界大觀, Samcheonli 三千里 10-1, January 1, 1938; Kim N., 2011: 416.

30) "Managed with Hardship for 150 Years, 'Jo Go-yak,' the King of Pharmaceutical Industry," Chosun ilbo, January 4, 1936; "The Document Concerning the Arrests in Cases of Violation of the Foreign Remittance Management Law 外國為替管理法違反 事件檢舉二關スル件,” Relationship Report of Heungeop Club in League of Yeonhui College, October 8, 1938, http:// db. history.go. kr. 
HUANG Yong-yuan : "Medicine of the Grassroots" : Korean Herbal Medicine Industry and Consumption during the Japanese Colonial Period

The manufacturing of patent medicines was not limited to large-scale herbal stores, but was common among the Uisaengs and merchants. Let us take the example of Jo In-seop's cousin Choe Geon-hul (崔健熙). After the Liberation, he was the third president of the Korea Oriental Drug Association (大韓韓藥協會); his father was an Uisaeng in the colonial period and ran the Bochang Hospital (普彰醫院) at No. 119, Sueun-dong (授恩洞) in Kyungsung. Based on his empirical formulas, Choe Geon-hul's father applied for permits for over 30 patent medicines, and established the Bochang Pharmacy (普彰製藥所) to make them (Choe, 1991: 53, 56). As Choe Geon-hul recalled, manufacturing skills were primitive at that time, and it was difficult to produce medicines in large quantities. Nonetheless, each pharmacy's medicines had their own unique characteristics, which meant that most medicine makers commercialized the "secret formulas" handed down by their forefathers (Choe, 1991: 53, 56).

It is worth noting that although Korean herbal stores made and sold patent medicines, and some even Western medicines, generally speaking, sales of traditional Korean decoctions and medicinal herbs still dominated. For example, in the 1930s, Cheon-il Yak-Bang registered the largest sale of patent medicine among all drugstores. However, sales of patent medicine accounted for only $20-30 \%$ of the total, and those of Korean herbal medicine continued to be its primary business (Hong, 1972: 110). Moreover, although Cheon-il Yak-Bang's business scope gradually expanded from traditional Korean herbal medicine to patent medicine, and even Western medicine, it continued to regard itself as the 
HUANG Yong-yuan : "Medicine of the Grassroots" : Korean Herbal Medicine Industry and Consumption during the Japanese Colonial Period

king of the Korean herbal medicine industry. ${ }^{31}$

The third type of Korean herbal stores were exclusive ginseng shops. Unlike ordinary medicinal herbs, Korean ginseng's effects were recognized worldwide early on, and it was famous in both East Asia and western countries such as the United States. Importantly, since ginseng was widely used as a supplementary medicine (補藥) in East Asia, demand for the drug was huge. Therefore, not only were common herbal stores selling it, but a group of chambers of commerce exclusively selling the herb also emerged. Of course, since the colonial authorities implemented a strict system of red ginseng monopoly, folk ginseng traders could only deal in white ginseng. ${ }^{32}$

31) Cheonil yakbo 110, April 25, 1931.

32) Ginseng was divided into that which was naturally grown and that which was artificially cultivated (also called false ginseng). Most of the naturally grown ginseng was produced in Kanggye (江界), Pyeonganbuk-do (平安北道). The artificially cultivated variety could be seen almost everywhere in Korea, although it was mainly cultivated in Gaesong (開城) of Gyeonggi-do (京畿道), Geumsan (錦山) of Chungcheongnamdo (忠清南道), and Punggi (丰基) (now Yeongju 榮州) of Gyeongsangbuk-do (慶劣 北道). Among these, Gaesong was the designated area for ginseng cultivation by the colonial authorities, who provided the ingredients for high-quality red ginseng. In 1908, the Japanese Resident-General issued and implemented the "Red Ginseng Monopoly Act (人衤專賣法), ” establishing the strict system of red ginseng monopoly. The colonial authorities granted permission to specific ginseng farmers, and appointed them to cultivate the herb. The harvested ginseng, that is, fresh ginseng (水茲), was entirely bought by the Monopoly Bureau (專賣局), and the good-quality ginseng was segregated, steamed, and made into red ginseng (紅衤), while the unqualified was turned over to farmers. The colonial authorities entrusted all red ginseng to Mitsui \& CO., LTD (三井物產), which exported it to China and other countries, but could not sell it in Korea. Nongovernmental organizations converted the ginseng that had been returned into white ginseng, and either sold it in the Korean market or exported it. Therefore, the ginseng that was handled by private ginseng merchants in areas including Gaesong, Geumsan, and Punggi, was white. "World-class Medicinal Properties, Pure Natural Ginseng 藥效도 世界的인 純天然產人菱,” Dong-a ilbo, January 29, 1936; Yang, 2013: 199, 214-216; "The Sacred Herb of the World, a Study on Korean Ginseng 世界의 神靈草 朝鮮人衤考(五),” Dong-a ilbo, May 15, 1934. 
HUANG Yong-yuan : "Medicine of the Grassroots" : Korean Herbal Medicine Industry and Consumption during the Japanese Colonial Period

Gaesong was the biggest beneficiary in terms of ginseng sales. The merchants there mainly sold white ginseng and its finished products, such as ginseng powder and extract. These were sold not only in Korea but also in Japan, Taiwan, Hong Kong, China, Southeast Asia, etc. ${ }^{33)}$ Organizations such as Korean Ginseng Trading Co. (高麗蓼業 社), Gaesong Ginseng Chamber of Commerce (開城人蓼商會), ${ }^{34)}$ and Korean Ginseng Chamber of Commerce (高麗白蔘商會) were the known ginseng chambers of commerce in Gaesong; among these, Korean Ginseng Trading Co. was the largest. Established in 1914, its members comprised ginseng planters, and the first president was a famous and wealthy businessman, Park Woo-hyeon (朴宇鉉) from Gaesong. In 1918, it turned into a joint venture, and shareholders included reputed names in Gaesong's ginseng industry and business community. The head of the company was the "King of Ginseng” Son Bong-sang (孫鳳祥), who was also the dean of the Gaesong Ginseng Union (開城氽業組合). In the early 1920s, Korean Ginseng Trading Co., with a registered capital of 200,000 won, was the leader in the Korean drug industry, and in the late 1920s, sales reached more than 400,000 won. ${ }^{35)}$

These chambers of commerce gradually expanded their business to sale of common Korean herbal medicines. Korean Ginseng Trading

33) Park Bong-jin 朴鳳鎮, “The Famous Specialty of Gaesong, Korean Ginseng 開城의 名 產 高麗人蓼, B Bandosiron 牛島時論1-7, October 15, 1917, p. 36; Isawa Yosihilo 石禾 義弘, “Park Woo-hyeon, the Central Figure of Gaesong 開城 中心的 人物 朴宇鉉氏, Bandosiron 1-7, October 10, 1917, p. 46.

34) “Gaesong Ginseng Corporation and Ginseng King Choe Ik-mo 開城人苑商會外 人蓼大 王 崔益模君,” Maeil sinbo, February 9, 1920.

35) Isawa Yosihilo, "Park Woo-hyeon, the Central Figure of Kaesong," Bandosiron 1-7, October 10, 1917, p. 45; “Pharmaceutical Company in Korea 鮮內 製藥會社,” Maeil sinbo, June 11, 1922; “Korean Ginseng Chamber of Commerce 高麗䓠業社," Dong-a ilbo, 1927; Yang, 2011: 100-101. 
HUANG Yong-yuan : "Medicine of the Grassroots" : Korean Herbal Medicine Industry and Consumption during the Japanese Colonial Period

Co. opened a branch in Hwanggeum-jung in Kyungsung in 1934, and simultaneously managed ginseng sales, patent manufacturing, and Korean herbal medicine trading. The Korean Ginseng Chamber of Commerce also opened a unit in Namdaemun-tong (南大門通) in Kyungsung and sold Korean herbal medicines, posting the signboard "Wholesale Medicinal Herb Store (乾材藥局)” (Figure 7).

Figure 7. Branch of the Korean Ginseng Chamber of Commerce in Namdaemuntong in Kyungsung ${ }^{36)}$

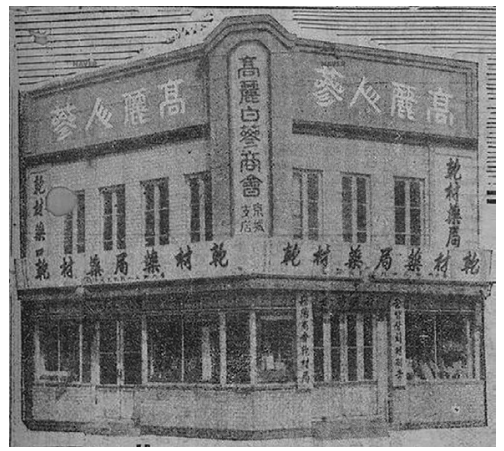

("Korean Ginseng and Antler, Chinese and Korean Medicinal Herb and Wholesale Medicinal Herb 高麗蓼茸 唐草乾材, ” Dong-a ilbo, April 12, 1928)

A significant feature of the commercialization of the traditional Korean herbal medicine industry was the drug market's internationalization. The industry in the colonial period was operating in an international environment and expanded overseas. First, the import of Chinese medicinal herb (that is Tangjae [唐材], in contrast with Chojae [草材], the Korean medicinal herb) was active. While in the period after the

36) "Korean Ginseng and Antler, Chinese and Korean Herb and Wholesale Medicinal Herb 高麗蓼茸 唐草乾材,” Dong-a ilbo, April 12, 1928. 
HUANG Yong-yuan : "Medicine of the Grassroots" : Korean Herbal Medicine Industry and Consumption during the Japanese Colonial Period

Liberation, the Korean herbal medicine community used nationalist slogans of "non-dualism (身土不二)" to emphasize that native medicinal herbs were superior to Chinese ones, in the colonial period, the latter were indispensable within the community.

Wang Shunfu (王順福), an active Chinese medicine apothecary in Kyungsung, recalled that in the 1920s, the proportion of Chinese medicinal herbs in a decoction amounted to as much as a third. ${ }^{37)}$ In the 1930s, the Daegu Market, the largest distribution center of Korean medicinal herbs, reported average annual sales of 4 million won, of which Tangjae sales accounted for 1.5 million won. ${ }^{38)}$ Thus, Korea imported a large amount of medicinal herbs from China every year, ${ }^{39)}$ which bred a group of drug sellers or businessmen importing Tangjae.

Overseas Chinese merchants in Korea at one point dominated the import market of Tangjae. For example, the famous businessman Tan Jiesheng (譚傑生) from Guangdong (廣東), China, who was the owner of Tong Shun-tai (同順泰), had arrived in Korea after the Im-o Military Revolt (壬午軍亂, 1882), and in his initial days, accumulated a large amount of capital through the import of Tangjae. Apart from Tong Shun-tai, there were other stores, such as Guang Rong-tai (廣榮泰), De

37) "New Customs and Daily Life (4) Chinese Herb, Chinese Herb Merchant Wang Shunfu Saying 新關稅外 日常生活(四) 唐材藥種, 唐材商王順福氏談,” Dong-a ilbo, September 7, 1920.

38) "Korean Local Specialty, Daegu Herbal Medicine Market, Faced a Predicament due to the Unavailability of Drug Materials, and Hundreds of Merchants Pleaded with the Japanese Government-General of Korea 朝鮮名物 大邱藥令市 藥材杜絶兵 自滅狀態 百 餘業者連名 總督府에 陳情, ” Dong-a ilbo, November 3, 1938.

39) According to data from the late 1930s, the import volume of herbs from China was as high as 2 to 3 million won per year (“Drug Seller Jo Jongguk (趙鐘國) Says, “Tangjae Imports Reduced by a Quarter. It's Urgent to Cultivate the Medicinal Herb'藥材業 趙鐘 國氏談, 唐材輸入 四分一減 栽培需給이 緊要,” Maeil sinbo, January 6, 1939). 
HUANG Yong-yuan : "Medicine of the Grassroots" : Korean Herbal Medicine Industry and Consumption during the Japanese Colonial Period

Sheng-heng (德生恒, the aforementioned outlets were in Supyo-dong [水標洞] in Kyungsung), Fu Yuan-dong (福源東, in Gwangsu-dong [觀水 洞]), Yong Feng-yu (永豊裕, in Nagwon-dong [樂園洞]), Yi Sheng-tang Pharmacy (益生堂藥房, in Jeongdong [貞洞]), etc. Among the merchants who personally traveled to China to import Tangjae were Park Gi-seung (朴基承) of Sunchang Yanghaeng (順昌洋行), the first president of the Korea Oriental Drug Association after the Liberation, and Choe Wonsik (崔元植) of Gwangnam Pharmacy (廣南藥局). ${ }^{40)}$ Cheon-il Yak-Bang hired Wang Qinsheng (王芹生) in 1931 from Shandong (山東) in China; he had once worked at the Chinese herbal store Fu Yuan-dong. He was appointed as the manager of the purchasing department and specialized in the import of Tangjae. ${ }^{411}$

Furthermore, Korean emigration had peaked during the colonial period. However, because they could not change their lifestyle and believed that it was inconvenient to visit a doctor in an alien country, overseas Koreans continued to largely depend on Korean herbal stores and doctors. Thus, the Korean herbal medicine industry expanded abroad (Tonomura, 2004: 137; Jung, 2014: 279). In Japan and Northeast China, Koreans operated a number of herbal stores, some of which functioned on a large scale.

In Japan, the Daeseong Chamber of Commerce (大聖商會) in Osaka (大阪) was particularly famous. Its owner Park Seong-o (朴聖吾) was born in 1893 in Hwanggeum-jung in Kyungsung. He inherited his

40) Shin, Gil-gu 申佶求, “Today and Yesterday of Korean Herbal Stores 漢藥局의 今昔(3),” Yageob sinmun 藥業新聞, July 27, 1967.

41) "Managed with Hardship for 150 Years, the King of Pharmaceutical Industry," Chosun ilbo, January 4, 1936; "The Document Concerning the Arrests in Cases of Violation of the Foreign Remittance Management Law 外國為替管理法違反事件檢舉二關スル件, ” Relationship Report of Heungeop Club in League of Yeonhee College, October 8, 1938, http:// db. history.go. kr. 
HUANG Yong-yuan : "Medicine of the Grassroots" : Korean Herbal Medicine Industry and Consumption during the Japanese Colonial Period

family's Korean medicinal herb business when he was 17 , and went to Osaka to establish the Daeseong Chamber of Commerce in 1932. After several years of work, the main store was set up in the Korean Market in Ikano-machi (豬飼野町) of Higashinari-ku (東城區), with a branch in Tenroku (天六) and a milling factory in Hiraoka (枚岡), establishing a large-scale operation for the enterprise. ${ }^{42)}$ In 1940, Park Seong-o returned to Korea and set up the Daeseong Pharmaceutical Corporation (大聖藥 業株式會社) in Daejeon (大田) to cultivate, sell, and process medicinal herbs. He also established branches in Osaka, and offices in Kyungsung and Tianjin (天津), China, becoming a veritable multinational Korean medicine merchant. ${ }^{43)}$

In addition to Park Seong-o's Daeseong Chamber of Commerce, Kim Chang-hyeon’s (金昌鉉) Bosaeng-dang Herbal Medicine Store (普生堂漢 藥房) in Osaka also operated on a large scale. Kim Chang-hyeon, born in Gangjin-gun, Jeollanam-do (全羅南道康津郡), commenced his business in Korean herbal medicine at the end of the Great Han Empire, and was proficient in traditional Korean medicine. He went to Osaka in 1927 and established Bosaeng-dang (普生堂). By 1937, he set up its main unit at Number 1, Chudo Hondori Street (中道本通) of Higashinari-ku (東城區), a milling factory in Midoriya-machi (綠屋町), and a pharmaceutical factory in Hoshutsu-machi (放出町), with the marketing network covering Japan, Korea, Manchukuo, etc. ${ }^{44)}$ (Figure 8).

42) "The Star of the Wholesale Medicinal Herb Industry, Park Seong-o, the Owner of Daeseong Business 乾材藥業手 惠星 大聖商會主朴聖吾氏,” Chosun ilbo, August 28, 1937.

43) "Daeseong Pharmaceutical Corporation, the Core Figure in the Korean Herbal Medicine Industry 漢藥界手 中核人物 大聖藥業株式會社,” Maeil sinbo, June 27, 1943.

44) "Kim Chang-hyeon, the Owner of the Bosaeng-dang Herbal Medicine Store 漢洋藥界의 霸王 普生堂藥房主 金昌鉉氏,” Chosun ilbo, August 28, 1937. 
Figure 8. Owners of Korean Herbal Store Bosaeng-dang in Osaka, Kim Changhyeon and his Son Kim Byeong-ryong (金丙龍).

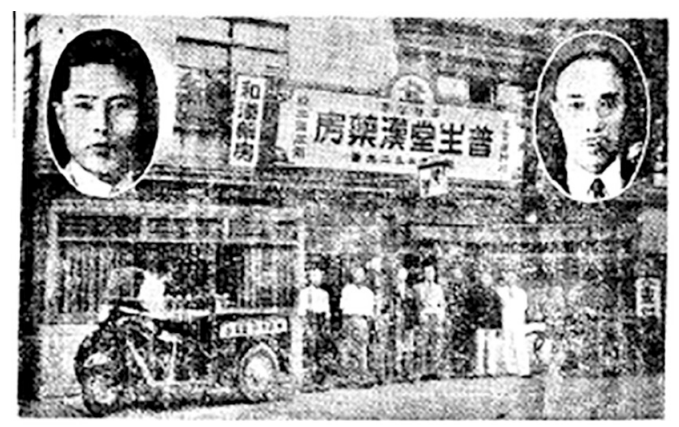

(“Bosaeng-dang Herbal Medicine Shop, Kim Chang-hyeon,” Chosun illbo, August 28, 1937)

In a show of cooperation toward Koreans in Japan, many Korean herbal stores in Korea provided medicinal herbs to stores run by Koreans overseas. Taechang-dang (泰昌堂) in Namsung-jung (南城町), the central point of the Daegu Market, was an example. Shin Seong-gyun (申聖均), ${ }^{45)}$ son of Shin Tae-moon (申泰文) who was the owner of Taechang-dang, recalled that his father often sold medicinal herbs by mail to herbal stores run by Koreans in Japan (Park G., 2011: 179). The bonds of nationality and the national health industry prompted the Korean-run herbal stores in Japan and Korean herbal medicine industry in the Korean Peninsula to form an industrial chain.

In line with this, although the colonial period was a time when Western

45) Shin Seong-gyun, born in Daegu in March 1921, studied at Ritsumeikan University in the 1940s and was recruited as one of the "Student Soldiers (學徒兵).” After the Liberation, he became a civil servant, working in tax administration. After passing the Korean Medical Qualification Examination in 1964, he set up the Shin Seong-gyun Korean Medical Clinic (申聖均漢醫院) in Daegu Market. One of his two sons was a pharmacist of Korean herbal medicine (漢藥業士) and the other a Korean medical doctor. Park G., 2011: 173-174. 
HUANG Yong-yuan : "Medicine of the Grassroots" : Korean Herbal Medicine Industry and Consumption during the Japanese Colonial Period

medicine gradually expanded, the Korean herbal medicine industry did not, as a result, witness any decline. The latter was closely connected to the daily routine of most Koreans; it was also one of the few "national industries" that Koreans could dominate. Thus, amid the policy of the colonial authorities, who vigorously supported Western medicine, the Korean herbal medicine industry maintained its strong sense of tradition and ability to actively adjust to the changes brought by the times.

\section{The Consumption of Korean Herbal Medicine in the Background of Interaction between New and Old Perspectives}

In modern Korea, although traditional Korean medicine and Western medicine co-exist, the general public, especially young Koreans, seem to believe that the use of the former is declining. This paper does not analyze the causes of this phenomenon, but it suggests that these developments may have prevented young scholars from making an objective judgment about the medical treatment during the colonial period. Some studies have indicated at the macroscopic level that the Korean society, especially in rural areas, was not covered by the western medical system in the colonial period. Instead, it was excluded from the "field" that was favored by modern Western medicine. During the colonial period, a crackdown by the colonial authorities affected traditional Korean medicine, but it was still one of the most important means for Koreans to maintain health (Shin C., 1999: 66-67; Lee, 2006: 235). Korean herbal medicines, the focus of traditional Korean medicine, were thus indispensable to the average Korean. 
HUANG Yong-yuan : "Medicine of the Grassroots" : Korean Herbal Medicine Industry and Consumption during the Japanese Colonial Period

For the citizens, however, the only aim of choosing between different medical treatments was to seek a cure and prevent diseases. In a particular medical practice, people were making decisions on various treatments under specific circumstances rather than being faithful to a certain style of treatment. Such choice indicated their active response to disease and revealed the interweaving and exchange of old and new ideas in the medical field in the colonial period. It reflected the tension between tradition and modernity during that time.

First, we have to acknowledge that around the 1910s, Koreans' attitude toward Western medicine gradually transformed from fear and hostility to acceptance and approval. For example, Won Deok-sang (元德常), who graduated from the Chiba Medical School (千葉醫學專門學校), had established the luxurious Deokje Hospital (德濟病院) in 1912 in Angukjeong (安國町), Kyungsung. He recalled that when the hospital was opened, people would come to see how the doctors used stethoscopes and thermometers as in a play, but not when they actually fell ill. They believed that taking Western medicines was equal to seeking death and that western doctors were agents of death. ${ }^{46)}$

Within a few years, however, this fear and unfamiliarity changed significantly. For example, on May 12, 1916, Maeil sinbo reported, "Western and Korean medicine have begun to co-exist. Everyone can seek medical treatment in accordance with their preferences. People who admire Western medicine opt for that treatment, including general medicine and surgery; similarly, people who value Korean medicine

46) "A Former Oriental Medicine Dealer, a Contributor to the Hygiene and Health of the Korean Peninsula 財界人風觀點景 適初漫筆-出身은 神農遺業에서 牛島生保界의 功勞者,” Maeil sinbo, July 2, 1940. 
HUANG Yong-yuan : "Medicine of the Grassroots" : Korean Herbal Medicine Industry and Consumption during the Japanese Colonial Period

receive Korean medical treatment; people who decide on medical treatment according to their situations usually choose Korean remedies for general medicine and western cure for surgery. This is not an absolute choice and there are various views. " ${ }^{477}$ However, what was obvious was that they were overcoming their fear of Western medicines, and the preference for medical treatments seemed more diverse.

Moreover, many people were confused about which treatment was the best. For example, in September 1918, Choe Won-sik (崔瑗植), chief writer of Jungoe-uiyag-sinbo (中外醫藥申報), said, “Recently, a complex situation has emerged in the medical field, where Western doctors and medicine, and Korean doctors and medicine have amalgamated. Thus, patients are apprehensive as to which one is better." ${ }^{48)}$ On May 4, 1924, an article in Chosun ilbo (朝鮮日報) stated, "Since the arrival of Western medicine, a consensus on which is the better option has not yet been reached in Korea." ${ }^{49)}$ An obvious example was the questions from readers in the correspondence column of Dong-a ilbo (東亞日報); many concerned the choice between Korean and Western medicine. For instance, a woman who suffered from a menstrual disorder due to dystocia during childbirth, wrote a letter seeking information on whether she should opt for Western or Korean medicine to conceive again; there was also a reader who was physically weak asking which tonic, Western or Korean, was better. There were many questions of a similar nature. ${ }^{50)}$

47) “Ever-changing Medicine and Traditional Korean Medicine 日新醫學과 漢方,” Maeil sinbo, May 12, 1916.

48) Choe Won-sik 崔瑗植, “Doctor and Medicine 醫와 藥," Bandosiron 2-9, September 10, 1918.

49) “Hygiene Conference and Herbal Doctors 衛生會議와 漢方醫,” Chosun ilbo, May 4, 1924.

50) “Family Library 家庭文庫,” Dong-a ilbo, 24; “Sanitary Adviser 衛生顧問,” Dong-a ilbo, 
HUANG Yong-yuan : "Medicine of the Grassroots" : Korean Herbal Medicine Industry and Consumption during the Japanese Colonial Period

This difficult choice indicated that Western medicine had gradually entered the day-to-day life of the average Korean.

However, it did not mean that the two systems were in disagreement. First, as mentioned above, at that time, Western medicine doctors and pharmacists were concentrated in urban areas, which largely limited the possibility of availing Western medicine. Second, the price of Western medicines was prohibitive for most Koreans. In many cases, patients would first try to take patent medicines, Korean herbal medicines, or other folk therapies, and only if all these failed, they would seek help from Western medicine doctors. ${ }^{51)}$ Even if they visited a hospital, they were turned away due to their socio-economic status. For example, writer Jang Hyuk-joo (張赫宙) published a novel Rainbow in the newspaper from 1933 to 1934 , and the following is a scene from it:

In Kyungsung, when Western medicine doctor Seo Younghwan (徐永煥) heard the pharmacist downstairs mention about a patient visiting, he was glad. However, he did not expect that the patient would be an old man, aged about 50 , from a remote village. He was carried by three farmers on a simple stretcher made of pine branches. Seo Young-hwan inquired about his symptoms perfunctorily, and then asked, "Have you brought money with you?" The old man motioned to his son to take the money from the pocket, and said, "We countrymen do not have much money. Here are about five won. Please provide medical treatment accordingly." Seo Young-hwan could not help but laugh, and answered, "Let me tell you. Your illness is too serious to be cured with only five or ten won. Besides,

November 1, 1929; "Hospital on the Newspaper 紙上病院," Dong-a ilbo, September 16, 1930.

51) "Find an Expert: Looking for a Doctor When You Are Ill 전문가를 차즈라 병에는 의사 를," Dong-a ilbo, August 20, 1927. 
HUANG Yong-yuan : "Medicine of the Grassroots" : Korean Herbal Medicine Industry and Consumption during the Japanese Colonial Period

you have to be hospitalized, and I am not sure if one or two months are enough for your healing. So, just go home and take Korean herbal medicine for treatment." "I cannot get medical treatment without money? Oh, I am from Daegu. I have visited five hospitals before coming here, but all had the same answer. Whoever knew that people nowadays are so cold-hearted?" Saying this, the old man asked the farmers to carry him away. ${ }^{52)}$

Jang Hyuk-joo's novel in this period was characterized as critical realism. The scenes described in it somewhat realistically depicted the medical field at that time. Since the 1920s, one of the most significant topics that people discussed was the prohibitive cost of Western medicines and treatment and the phenomenon of money worship. ${ }^{53)}$ The aforementioned scene highlighted this reality. In the Western medicine doctor Seo Young-hwan's opinion, poor patients only deserved Korean medical treatment. The choice between Korean and Western medicine seemed to be naturally associated with fortune and social rank, creating a new benchmark of status.

However, when Koreans chose to take Korean herbal medicine, it was not only because of financial constraints. We should not overestimate the development of Western medicine in the colonial period. In fact, Western medicine was useless in curing many diseases at that time. For example, the Spanish flu hit Korea in the autumn of 1918, and 7.5 million of the 17 million population was infected. The death rate was $0.82 \%$

52) “Rainbow 무지개," Dong-a ilbo, February 9, 1934.

53) “Surging Prices Only in Drugs 唯獨藥價騰貴, ” Maeil sinbo, May 28, 1921; “Huge Profits Made by Medical Workers," Dong-a ilbo, March 28, 1924; "Drug Prices and Treatment Costs," Byeolgeongon 別乾坤 32, September 1, 1930. 
HUANG Yong-yuan : "Medicine of the Grassroots" : Korean Herbal Medicine Industry and Consumption during the Japanese Colonial Period

(Kim T. J., 2017: 163). While western doctors expressed helplessness, the traditional Korean prescriptions of the Uisaengs, such as ToxinVanquishing Powder (敗毒散), Harmonious Flow Decoction (沖和湯), Flesh-Resolving Decoction (解肌湯), and Ephedra Decoction (麻黄 湯) showed favorable results. Even Japanese settlers and the Western medicine doctors supposedly took the aforementioned Korean drugs. ${ }^{54)}$

Another example was tuberculosis, a chronic infectious disease and an epidemic at that time. Since western doctors did not have an effective treatment for it, Western and Korean medicine began competing with each other to discover how to prevent and treat it (Choe, 2011: 187-188). The following is an excerpt from the medical treatment record of Lee Sun-yeong (李順泳, probably a writer or journalist) in Oriental Medicine (東洋醫藥):

"I was diagnosed with tuberculosis by a provincial hospital on February 19, 1934. Subsequently, I availed medical treatment at the hospital for 40 days, but it had no effect. My grandfather advised me to take Korean herbal medicine initially, but I was apprehensive about taking it since I had graduated from the Secondary School (高等普通學校), so I ignored his advice. Nonetheless, I had no choice but to visit the Uisaeng recommended by my grandfather. I told the Uisaeng about my diagnosis, the process of medical treatment, and its effect in the provincial hospital. The Uisaeng examined me for a while and said, "No, they are wrong. Tuberculosis is the name they (Western medicine doctors) created. You are deficient in Yangqi (陽氣不足). You will recover after taking the medicine to supplement your Yang-qi." I took 40 doses of the medicine

54) “Worldwide Influenza," October 23, 1918, Sogeumcheongsa（續陰晴史 Kim Yunsik's Diary), v. 17, http:// db. history.go. kr; "Influenza History and Korean Doctors' Achievements," Bandosiron 3-1, January 10, 1919, p. 58. 
HUANG Yong-yuan : "Medicine of the Grassroots" : Korean Herbal Medicine Industry and Consumption during the Japanese Colonial Period

prescribed by the Uisaeng, and I was miraculously cured." ${ }_{55}$

Lee Sun-yeong was neither too poor to receive western medical treatment, nor did he favor traditional Korean medicine. It was only because of the former's ineffectiveness that he turned to Korean doctors and medicine. Despite having enough money, most patients were faithful to neither system and just tended to choose the most effective treatment for themselves. In 1930, the Western medicine doctor Kim Eun-sun (金 殷善), who set up Chung Hwa Hospital (淸華醫院) in Goyang-gun (高 陽郡), Gyeonggi-do (京畿道), said, “Koreans fluctuate between Korean medicine and new medicine. For example, they consulted new doctors (Western medicine doctors), and were told they could recover within 20 days, but when they heard that Korean doctors could cure patients with several doses of decoction, they immediately changed their mind and took Korean herbal medicine. When that failed to help, they turned to modern medicine. They constantly changed their line of treatment, and thus became incurable in many cases. ${ }^{\text {56) }}$

The conflict between the two systems was not rare in works of literature either. Take the case of the hero Heo Il (許日) in the novel The Third Slave (第三奴隷) written by Lee Geun-yeong (李根榮) in 1938. He was diagnosed with pneumonia by the affiliated hospital of Keijo Imperial University (京城帝國大學) (that is, the Japanese Government-General Hospital). However, since he believed that Korean herbal medicine was

55) Lee Sun-yeong, "Pulmonary Tuberculosis and Herbal Medicine- - the Confession of an Ordinary Person 肺結核과 漢方藥——素人으로서의 告白,” Oriental Medicine February 2, 1935, pp. 65-69.

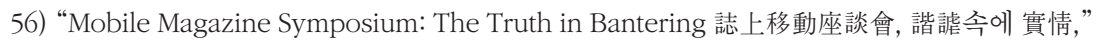
Byulgungon, May 28, 1930, p. 89. 
HUANG Yong-yuan : "Medicine of the Grassroots" : Korean Herbal Medicine Industry and Consumption during the Japanese Colonial Period

better than western, he went home and took expensive supplementary drugs. Subsequently, his health deteriorated; he then chose to get admitted in the hospital to receive western medical treatment. ${ }^{57)}$

In some cases, patients would choose to take both Korean and western forms of treatment. The third leader of the Chendo-gyo Religion (天道敉) Son Byeong-hui's (孫秉熙) experience late in his life is an example. In 1919, because Son Byeong-hui led the March 1st Movement (三一運動) as one of the 33 national representatives, he was arrested and imprisoned by the colonial authorities. In December 1920, he was released on medical parole after falling seriously ill. Suffering from multiple diseases such as arteriosclerosis, diabetes, and pleurisy, he was lodged in the villa of Sang Chun Won (賞春園) outside Dongdaemun (東大門) for recovery. The director of the Chendo-gyo Religious Hospital, Park Jong-hwan (朴宗桓) was his attending Western medicine doctor. ${ }^{58)}$ In addition, the Uisaeng Park Chan-su (朴燦洙) was invited to administer Korean medical treatment. Moreover, he also took the Korean herbal medicine prescribed by the famous Uisaeng Kim Hong-je (金弘濟) from Hamheung (咸興). Therefore, when Son Byeong-hui passed away in May 1922, Park Jonghwan shifted all responsibility to Park Chan-su. ${ }^{59)}$

For an average family, besides these two systems, there was also folk medical treatment and Shamanism. These were always administered in combination and would compete with each other. For example, on March

57) “The Third Slave 第三奴隸 (82),” Dong-a ilbo, June 10, 1938.

58) "The Establishment of Chondoism Hospital 천도교 병원 설립," Maeil sinbo, March 28, 1913.

59) “The Condition of Son Byeong-hui Under Police Officers' Strict Supervision 警官의 嚴 重한 監視下에 近日孫秉熙의 病勢),” Dong-a ilbo, February 28, 1921; “Son Byeong-hui is Deathly Ill 孫秉熙氏危篤,” Dong-a ilbo, May 17, 1922; “Son Byeong-hui Gone Forever 孫秉熙先生의 長逝, The Independent 독립신문, May 27, 1922. 
HUANG Yong-yuan : "Medicine of the Grassroots" : Korean Herbal Medicine Industry and Consumption during the Japanese Colonial Period

23, 1927, an article in Dong-a ilbo titled "Let's Get Our New Women Out of Superstition" vividly described the general treatment in a Korean folk family. "Now let us check the situation in an old family. If a family member is sick, Korean herbal medicines and Western medicines are taken together. Simultaneously, a blind man comes through the front door ${ }^{60)}$ and the witch comes through the back door. It is a unique situation that you can rarely find in other countries." ${ }^{11}$

Furthermore, throughout the colonial period, although the general power and influence of Western medicine was expanding, Korean herbal medicine's market share did not decrease sharply; in fact, it rose every so often. The first period was around World War I. Given that Western medicine and imported raw materials were deficient and expensive, the Japanese Home Ministry suggested that medicines should be prepared at home; they thus began to pay attention to domestic medicinal herbs and committed to the cultivation, experimentation, and research of drugs. ${ }^{62)}$ Under these circumstances, the market for Korean herbal medicine thrived.

The second period was after the mid-1920s. During this time, the Japanese Kampo (Traditional Japanese Herbal) medical community

60) At that time, Korea had folk customs that involved asking the blind to chant the scriptures (讀經), to drive the sickness away, and pray.

61) "The New Women. Let's Destroy Superstitions 우리신녀성은 미신을 타파합시다," Dong-a ilbo, March 23, 1927.

62) "The Research on Herbs Trial Plantation, The Interior Ministry's New Attempt, The War Caused Drug Eradication 薬草の試植研究 内務省が新しい試み大戦で薬品杜絶が動 機になる,” Karafuto nichi-nichi shinbun 樺太日日新聞, January 20, 1918. The Home Ministry of Japan commissioned the Tokyo Imperial University and the Agricultural Trial Site (農事試驗場) of the Ministry of Agriculture and Commerce (農商務省) to promote herb cultivation and establishment of a national herb garden so as to achieve self-sufficiency in medicines ("The Establishment of a National Herb Garden 國立藥草 園의 設置,” Gyelim uisa wisaeng 鷄林醫事衛生, February 2, 1921, p. 73). 
HUANG Yong-yuan : "Medicine of the Grassroots" : Korean Herbal Medicine Industry and Consumption during the Japanese Colonial Period

launched a campaign for its revival. In addition, some people from the Western medicine community, represented by Prof. Asahina Yasuhiko（朝 比奈泰彦) of the Faculty of Medicine at Tokyo Imperial University (東京帝 國大學), also believed that chemical medicine and single substance drugs were limited, so they advocated the importance of Kampo medicine and its prescription (Pan \& Fan, 1994: 303-304). During the same period, Keijo Imperial University, set up by the Japanese in Korea, also regarded the research of Korean medicinal herbs as an important development for itself. ${ }^{63)}$ Although the research was ultimately used for chemically extracting the effective ingredients from the herbs, and inventing new medicines, it categorically increased public attention on Korean herbal medicine, and strengthened the reputation of traditional Korean medicine to a large extent (Huang, 2018: 219-220).

Moreover, in 1933, the Government-General, which wanted to alleviate the impact of the Great Depression on the Korean countryside, launched “the Campaign of Award for Cultivating Medicinal Herbs (藥草栽培獎勵運 動)" across the country. ${ }^{64)}$ The public at that time had termed it as "the period of Korean herbal medicine" and "the golden age of medicinal herbs," and it made people believe that the situation had changed again after many years of the spread of Western medicine to the East. ${ }^{65)}$ In

63) Hastoli Unokichi 服部宇之吉, “Characteristics of the Kei-jo Imperial University, Being the Authority on Traditional Korean Medicine, Oriental Language and Korean Studies 朝鮮帝大の特色, 漢藥と東洋語と朝鮮との研究が權威である, ” Chosun sinmun, March 1, 1924; Shin C., 2007: 126-131.

64) “Accelerating the Self-made Herbs' Cultivation 自力更生に拍車をかける藥草栽培,” Chosun 朝鮮 215, April 1933, p. 160.

65) "With the Advent of the Korean Herbal Medicine Era, Scholars also Went on a Trip to Look for Famous Drugs, as Did Kei-jo Imperial University 漢藥時代到來 명약 찻고 저 학자도 출장, 城大에서도 大努力," Dong-a ilbo, February 19, 1933; “The Golden Age of Herbs 藥草黃金時代,” Osaka asahi shimbun Chosun version 大阪朝日新聞 朝鮮版, 
HUANG Yong-yuan : "Medicine of the Grassroots" : Korean Herbal Medicine Industry and Consumption during the Japanese Colonial Period

1937, as the Sino-Japanese War started, the import of not only Western medicines but also Tangjae from China decreased significantly, and thus, Korean society's dependence on the herbal medicines made in Korea increased. In short, throughout the colonial period, we can say with certainty that Korean herbal medicine was not marginalized or greatly impacted because of the importation of Western medicine.

Hereinabove, this paper mainly analyzes and summarizes the consumption of Korean herbal medicines in the Korean medical market at that time on a macro level. Finally, two figures' diaries are examined to draw a picture of said consumption and the medical situation in the Korean society on a micro level.

First, let us read the story of Kim Yun-sik (金允植, 1835-1922), who was also known as Unyang (雲養). He was an invincible political leader at the end of the Great Han Empire, as well as a moderate reformer (穞 健開化派), senior official, and scholar. There were many medical records in his diary Sogeumcheongsa (續陰晴史, 1887-1921). Since Kim Yun-sik was active and highly placed in the diplomatic field at the end of the Great Han Empire, he had more opportunities than the general public to learn about Western medicine, although he had crossed the age of 50 by the late 1880s. He often consumed quinine to cure malaria around 1891. Because he was then exiled to Mincheon (泟川, currently Mincheonmyeon [沍川面], Dangjin-si [唐津市], Chungcheongnam-do [忠清南道]), and could not adapt to the southern environment, he frequently took quinine. Thus, he could identify which consignment of the drug from the peddlers was fake. ${ }^{66)}$ Moreover, when he returned to Seoul in 1895, he

August 28, 1933.

66) Sogeumcheongsa (1), v. 6, 7, May 9, 1892. 
HUANG Yong-yuan : "Medicine of the Grassroots" : Korean Herbal Medicine Industry and Consumption during the Japanese Colonial Period

began to receive medical treatment from western doctors. For example, in February 1895 of the lunar calendar, he began coughing and also reported a large amount of phlegm. When he failed to recover even after taking Korean herbal medicine, the British doctor Boord came to visit him and gave him two bottles of Western medicines-one was to cure the cough, and the other a supplement of qi (氣). ${ }^{67}$

In the 1900s, Kim Yun-sik had a deeper sense and understanding of Western medicine. On April 16, 1908, he was administered anesthesia by the American doctor Avison, the dean of Jejungwon (濟衆院), when he underwent a tongue surgery. Although Kim said, "The anesthesia is too poisonous, as I had a headache and edema in my throat after that. I had difficulty in swallowing food, and I suffered a lot," it was indeed an unforgettable experience for him. ${ }^{68)}$

There was, however, a more dramatic experience. In April 1908, his son Chamseo (參書) was “coughing up blood for a long time, and he had fever and could not eat. So he became very skinny and contracted Nochae (勞 瘵, the pattern of pulmonary tuberculosis)." Thinking “ordinary doctors could not heal him,” Kim invited An Sang-ho (安商浩) to see his son. An Sang-ho had graduated from the Tokyo Jikei Medical College (東京 慈惠醫學專門學校) and was the first Korean to acquire the license of a Japanese doctor. He examined Chamseo's sputum under a microscope. Kim recorded: "There are five or six thin red worms in the sputum, that are bacteria. The doctor said the name of the disease is tuberculosis." ${ }^{99}$ The western doctor could not cure Chamseo, but Kim had practical

67) Sogeumcheongsa (1), v. 7, February 29, 1895.

68) Sogeumcheongsa (2), v. 13, April 16, 1908.

69) Sogeumcheongsa (2), v. 13, April 22, 1908. 
HUANG Yong-yuan : "Medicine of the Grassroots" : Korean Herbal Medicine Industry and Consumption during the Japanese Colonial Period

experience of Western medicine, which was based on the theory of bacteria.

Additionally, in March 1908 (Kim Yun-sik was 74 then), when he barely had any teeth in his lower jaw, he first went to the Nozu Dental Clinic (野津齒醫所) set up by the Japanese in Myeongdong (明洞) and then to a dental clinic run by Americans in Sangdong (尙洞) for artificial teeth. Before the Japanese Annexation of Korea, Kim was about 70, but as an exponent of the idea of Dongdoseogi (東道西器) among the group of moderate reformers, he was open-minded toward Western medicine.

After the Japanese Annexation of Korea, the colonial authorities bestowed the title of viscount on him. Although he did not have any actual political power, he was rich and famous. Thus, the medical resources he and his family could use, as compared with those available for the common folk, were sufficient. According to his diary, famous Uisaengs from various places had checked the pulse and prescribed treatment for him and his family, such as Chae Eung-rok (蔡應祿) in Gyeongwon (慶源), Lee Hyeon-jae (李顯宰) in Changwon (昌原), and Jo Byeong-geun (趙炳 瑾), Seo Byeong-hyo (徐丙孝), and Kim Seong-gi (金性璂) in Kyungsung. Concurrently, Kim Yun-sik had acquired the resources of top western doctors. He maintained a good relationship with the American doctor Avison, Korean Western medicine doctor An Sang-ho, and military doctor Sato Tsunemaru (佐藤恒丸) of the Government-General. We can say that the challenges faced by the common man to avail medical services did not bother Kim. Meanwhile, from the perspective of medical resource availability, Korean and Western medicine were not different for him.

Nonetheless, he and his family preferred Korean herbal medicine as their main line of treatment until Kim passed away in the early 1920s. 
HUANG Yong-yuan : "Medicine of the Grassroots" : Korean Herbal Medicine Industry and Consumption during the Japanese Colonial Period

Whether it was general medicine or surgery, they always chose Korean herbal medicine after an Uisaeng's examination, and only after trying several ineffective prescriptions would they be persuaded to turn to a western doctor.

For example, in December 1921, Kim Yun-sik felt there was a stagnation of qi in his stomach, and then, Kim Seong-gi (金性基), who often visited him and shared a good personal relationship with him, decided that it was caused by wind-heat common cold (感熱), and a Toxin-Vanquishing (敗毒) drug should be taken for recovery. Therefore, he gave him three packets of Supplemented Qi-Righting Decoction (加味正氣湯). After Kim Yun-sik had taken the decoction for several days and it had not proved effective, his relatives and friends recommended other good doctors for him; yet, he still preferred to discuss the treatment with Kim Seong-gi. Later, he invited the western doctor Kim Yong-chae (金容彩) to see him. Kim Yong-chae diagnosed the disease as "pleurisy," and claimed that thoracentesis and medication were both needed for therapy. Kim Yunsik found that reasonable and decided to try the treatment. ${ }^{70)}$

Throughout Kim Yun-sik's experience with western doctors, we cannot say he had any bias toward Western medicine, and he even had more experience with it than common people did. Interestingly, however, like what has been mentioned above, all his life, Kim did not want to abandon Korean medical treatment unless it was absolutely necessary.

Now, let us turn our focus from Kyungsung to other areas. There was a man called Lee Byeong-gon (李炳鯤, 1882-1948) who lived in Toe Rori (退老里), Milyang-gun (密陽郡, now known as Milyang-si [密陽市]),

70) Sogeumcheongsa (2), v. 18, December 29, 1921. 
HUANG Yong-yuan : "Medicine of the Grassroots" : Korean Herbal Medicine Industry and Consumption during the Japanese Colonial Period

Gyeongsangnam-do (慶向南道). His family belonged to the famous Lee family of Yeoju (騼州, located in Gyeonggi-do), and he was a traditional and prosperous landowner. The family began to actively absorb new learning techniques after the end of the Great Han Empire, and established the Hwasan School (華山義塾) in 1907, inviting Japanese teachers to teach the techniques to all family members. The atmosphere in his family had greatly affected Lee Byeong-gon. He accepted the education of Confucianism in his early years and was especially skilled in the learning of rituals (禮學). He persisted in traditional learning, and at the same time, paid attention to modern civilization. Although he was living in a remote place, he often visited Kyungsung, Daegu, and Busan, witnessed the emerging society, and paid close attention to current affairs by reading newspapers like Maeil sinbo and Dong-a ilbo. Moreover, he also sent the men in his family to Kyungsung for higher education. In 1921, Lee and his family members established in his native town another private elementary school called the Jeongjin School (正 進學校), a modern educational institution, and he was its headmaster for many years. He studied both traditional and new educational styles, and we can say that he was a rare figure in the Confucian community around Yeongnam (嶺南). ${ }^{71)}$

Lee Byeong-gon had extensive knowledge in the field of medicine, and held the strong tradition of a Confucian physician (儒醫). As an intellectual persisting in Confucian ethics, he focused on whether he could use his medical knowledge to cure his parents' diseases as a mark of respect toward them. In reality, medicinal resources were limited in

71) Toesujaeilgi (退修齋日記 Toesujaeilgi's Dairy) (1) (Gwacheon: National Institute of Korean History, 2007), p. 13. 
HUANG Yong-yuan : "Medicine of the Grassroots" : Korean Herbal Medicine Industry and Consumption during the Japanese Colonial Period

the remote countryside, and thus, expanding his knowledge of medicine was a struggle for survival. He owned typical Korean medical books, such as Donguibogam (東醫寶鑑) and Bangyakhappyeon (方藥合編); they were an important source of medical knowledge for him. ${ }^{72)}$ Moreover, Lee Byeong-gon's cousin Lee Byeong-won (李炳瑗) set up a Korean herbal store, which helped Lee Byeong-gon's family take advantage of medical services, and at the same time, verified and promoted his medical knowledge through communication. ${ }^{73)}$

We can find in Lee Byeong-gon's diary (1906-1945) that when he or his family members fell sick, he often sought treatment from the herbal store owned by Kim Hwa-sun (金和善), Kim Dong-su (金童壽), and Kim Jongchae (金鍾采), which was about $2 \mathrm{~km}$ away. If the prescription was not effective, he would travel another $8 \mathrm{~km}$ to Milyang-eup, or even further in search of treatment. On May 8, 1911, when his mother was sick, he first purchased medicines from Kim Hwa-sun's herbal store. After his mother did not respond to those, on May 13, he went to Daegu, which is over $60 \mathrm{~km}$ away, to invite Jang Du-hwan (張斗煥) to treat his mother but was unable to meet the doctor. Later, Lee invited Kim Hyeon-chan (金顯燦) in Changwon-gun (昌原郡), which is $50 \mathrm{~km}$ away, twice. ${ }^{74)}$ In addition, he had also invited Lee Chun-hae (李春海) in Busan, which is 80 km away, many times for diagnosis and prescriptions for himself or his family, and visited doctors in Busan. His channels for medical treatment were numerous (see Figure 9). ${ }^{75)}$ Furthermore, the Gyeongbu Railway Line (京釜線) passing through Daegu, Milyang, and Busan had become

72) Toesujaeilgi (2), v. 15, May 14, 1945, pp. 278-279.

73) Toesujaeilgi (2), v. 15, p. 21.

74) Toesujaeilgi (1), v. 5, May 8-June 2, 1911, pp. 172-176.

75) Toesujaeilgi (1), v. 9, August 20-24, 1927, pp. 423-424. 
HUANG Yong-yuan : "Medicine of the Grassroots" : Korean Herbal Medicine Industry and Consumption during the Japanese Colonial Period

operational in 1905; thus, it was convenient to avail medical treatment from other places.

Figure 9. Current Administrative District of Milyang (密陽)

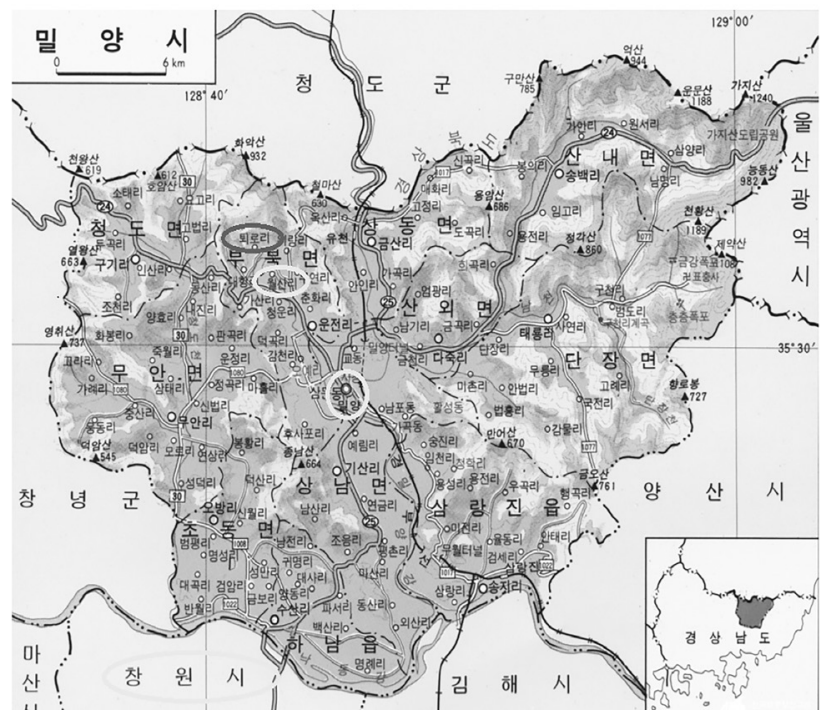

Note: Milyang is located at the intersection of Gyeongsangnam-do (慶䏌 南道) and Gyeongsangbuk-do (慶咼北道). Toe Ro-ri where Lee Byeonggon lived is marked with a red circle. Wolsan-ri (月山里), Milyang-eup (密 陽邑), and Changwon (昌原) from the upper to lower part on the map are marked in yellow circles. Daegu is in the northwest of Gyeongsangnamdo (upper part of the map), and Busan is in the southeast at the bottom of the map (Naver Image).

Although Lee Byeong-gon sometimes purchased medicines from Korean herbal stores, in many cases, he chose to order medicinal herbs from the Daegu Market. He would also personally prepare, even grind and process, the medicinal herbs into pills. For example, on March 12, 1927, when he was preparing drugs at home, his uncle visited him 
HUANG Yong-yuan : "Medicine of the Grassroots" : Korean Herbal Medicine Industry and Consumption during the Japanese Colonial Period

with a prescription "Bomyeong-dan (保命丹)" for his cousin who was afflicted with wind impediment (風疾). Since many medicinal herbs from the prescription were difficult to source, Lee Byeong-gon said: "Since uncle doesn't have trustworthy doctors, you can leave the prescription with me, I'll make it." He helped his uncle order medicinal herbs from Daegu by mail, and carefully dried and ground them with help from other family members ${ }^{76)}$ The reason Lee Byeong-gon did not buy from stores or doctors, but bought the raw materials to process and prepare the medicine himself was possibly because "uncle doesn't have trustworthy doctors to make it." He did not believe the merchants or doctors would make the medicine honestly. At that time, it was common for families to order raw materials from the market or stores for making or processing medicines at home.

As mentioned earlier, Lee Byeong-gon was unprejudiced toward modern western society; hence, he did not reject Western medicine. For example, as early as March 1910, when his son Heunglyong (興龍) had been sick for a long time, he heard that "An Sang-ho set up a clinic in Kyungsung and amazingly cured diseases with foreign medicine effectively." He decided to "resort to his treatment $\cdots$ however far he had to travel." He also wrote to An Sang-ho's friend Ah Geun-hoe (安根 晦) to inquire about An Sang-ho's medical skills. ${ }^{77}$ This indicates that Lee Byeong-gon had begun to try Western medicine. Yet, there were only a few records on Lee and his family's treatment with Western medicine, except that they occasionally took so-called "Japanese medicine" (possibly patent medicine), and that in 1929 and 1931, he visited a

76) Toesujaeilgi (1), v. 9, March 12, 1927, p. 382.

77) Toesujaeilgi (1), v. 3, February 18, 1910, p. 382. 
HUANG Yong-yuan : "Medicine of the Grassroots" : Korean Herbal Medicine Industry and Consumption during the Japanese Colonial Period

Japanese hospital in Milyang-eup for issues such as face ringworm (面鷹), tooth filling, and foot disease. ${ }^{78)}$ In terms of medical resource availability, Lee Byeong-gon obviously could not be compared with a senior official such as Kim Yun-sik in Kyungsung. Nonetheless, if we take into account Lee's financial capability for affording long journeys to places like Daegu, Changwon, and Busan, or inviting traditional medicine doctors to his house, it can be inferred that his family could easily receive western medical treatment if they desired. Furthermore, Lee Byeong-gon was born almost half a century after Kim Yun-sik.

Kim Yun-sik and Lee Byeong-gon certainly do not represent the Koreans during the colonial period. However, I surmise that their experiences could reflect the picture of medical practices in colonial Korean society, where both old and new treatments collaborated. Different from the impoverished masses who could hardly afford to avail Western medicine, Kim Yun-sik and Lee Byeong-gon enjoyed better geological and economic conditions, and greater accessibility to Western medicine, but they continued to use Korean herbal medicines as part of their regular treatment; Western medicine was only a supplementary option or an alternative. I believe that one reason for this is the inertia of tradition, and another that Western medicines were not necessarily effective for diseases that could not be cured by traditional Korean medicines. In other words, Western medicine lacked greater appeal and was not influential enough to break the monopoly of traditional Korean medicine in the medical world.

78) Toesujaeilgi (1), v. 10, January 18, 1929, p. 494; Toesujaeilgi (1), v. 10, April 14, 1929, p. 521; Toesujaeilgi (1), v. 10, June 1, 1929, p. 535; Toesujaeilgi (1), v. 11, October 23, 1931, p. 732. 
HUANG Yong-yuan : "Medicine of the Grassroots" : Korean Herbal Medicine Industry and Consumption during the Japanese Colonial Period

\section{Conclusion}

From the perspective of decrees, systematic methods, public health, medical education, hospitals, and medical practitioners, the colonial period was certainly a crucial time for Western medicine to take root and spread in Korea. Nonetheless, does that suggest that the use of traditional Korean medicine was waning? Or is the interaction between the two bound to result in gains for one at the cost of the other? If we only look from the perspective of the "Uisaeng," it is undeniable that traditional Korean medicine actually faced a serious crisis due to the policies implemented by the colonial authorities that restrained the Uisaengs in several aspects such as legal status, license, and education. However, if we take Korean herbal medicine into consideration, and approach the historical scene from the perspective of medical consumption, we have to reflect on the following: is our view of modern medical treatment in the colony swayed by the reality of the modern Korean medical industry? In colonial Korea, whether in the medical industry or daily life of common people, Eastern and Western medicine did not experience a dramatic alternation, and the latter did not fundamentally change Korean society's medicine consumption trend. Both in cities and villages, Western medicine, more or less, became an option for people-for most, it was only a supplement to Korean medicine in their regular medical treatment. This even holds true for the middle and upper classes who did not face economic and geographical obstacles in receiving western medical treatment. The above analysis is the fundamental reason why the Korean herbal medicine industry did not suffer during the colonial period. If the mentioned facts are accepted, undoubtedly, it is necessary 
HUANG Yong-yuan : "Medicine of the Grassroots" : Korean Herbal Medicine Industry and Consumption during the Japanese Colonial Period

for us to reposition traditional Korean medicine in medical history and the narration of medical modernization during the colonial period, and pay more attention to the inheritance of and change in traditional Korean medicine and the interaction between Eastern and Western medicine.

Keywords: Korean Herbal Medicine; Korean Herbal Medicine Industry; Traditional Korean Medicine; Korean Medicine Merchant; Chosun; Japanese Colonial Period; Consumption; Tradition; Medical Modernization

Received: Jan. 31, 2020; Reviewed: Feb. 28, 2020; Accepted: Apr. 09, 2020 
HUANG Yong-yuan : "Medicine of the Grassroots" : Korean Herbal Medicine Industry and Consumption during the Japanese Colonial Period

\section{REFERENCES}

〈Primary sources>

Bandosiron (牛島時論)

Byeolgeongon (別乾坤)

Cheonil yagbo (天一藥報)

Chosun (朝鮮)

Chosun and manchuria (朝鮮及滿洲)

Chosunchongdogbu gwanbo (朝鮮總督府官報)

Chosunchongdogbu josa wolbo (朝鮮總督府調查月報)

Chosun ilbo (朝鮮日報)

Chosun sinmun (朝鮮新聞)

Chosun yaghaghoe jabji (朝鮮藥學會雜誌)

Chungnam uiyag (忠南醫藥)

Daehan maeil sinbo (大韓每日申報)

Dong-a ilbo (東亞日報)

Dongyang uiyag (東洋醫藥)

Gyelim uisa wisaeng (鴙林醫事衛生)

Gyeongmu hwibo (警務彙報)

Hwanggeumdang yagbo (黄金堂藥報)

Iji Shinbun (醫事新聞)

Karafuto nichi-nichi shinbun (樺太日日新聞)

Maeil sinbo (每日申報)

Osaka asahi shimbun Chosun version (大阪朝日新聞朝鮮版)

Samcheolli (三千里)

The independent (獨立新聞)

Yageob sinmun (藥業新聞)

Sogeumcheongsa (續陰晴史)

Toesujaeilgi (退修齋日記 Toesujaeilgi's dairy) (National Institute of Korean History, 2007).

Explanation Data for the 73th Imperial Council 第73回帝國議會說明資料, CJA00024711937, National Archives of Korea.

Gyeonggi-do wisaenggwa ed. (京畿道衛生課編 Gyeonggi Provincial Hygiene 
HUANG Yong-yuan : "Medicine of the Grassroots" : Korean Herbal Medicine Industry and Consumption during the Japanese Colonial Period

Department ed.), Wisaeng gaeyo (衛生概要 Sanitary Outline), 1937.

Gyeongmu chonggambu wisaenggwa 警務總監部衛生課, Chosun wisaeng beobgyu yujib (朝鮮衛生法規類集 Collection of the Rules of the Chosun Sanitation Act) (Not for sale, 1917).

Haenimseowon ed. 杏林書院編, Dangi wanseong Singui Hanyagjongsang siheom jeongbog ((短期完成) 新規漢藥種商試驗征服， (Short-term Completion) Conquering the New Korean Medicine Merchant Trial) (Kyungsung: Haenimseowon, 1938).

Pyeongannam-do gyeongmubu ed. 平安南道警務部編纂, Wisaeng gyeongchal gangui ilban (衛生警察講義一斑 Hygienic Police Instructor) (Pyeongannam-do gyeongmubu, 1913).

Shiroishi Hosei 白石保成, Korean Hygiene Essentials 朝鮮衛生要義 (Not for sale, 1918).

\section{$\langle$ Secondary sources $>$}

Choe Eun-gyeong, "Study of the Epidemic of Tuberculosis and Responses in Korea during the Japanese Colonial Period,” Ph.D. diss., Seoul National University, 2011.

Choe Geon-hul, 80 years of Korean Herbal Medicine: Autobiography of Deogam Choe Geon-hul 韓藥八十年-德岩崔健熙自傳 (Seoul: Cheon-il Yak-bang 天一藥房, 1991).

Choe Yeong-sug, "A Study on an Official Medicine Market of Taegu-Changes after Gap-O Reform (1894),” Master’s diss., Sookmyung Women’s University, 1975.

Hong Hyeon-o, History of Korean Pharmacy 韓國藥業史 (Seoul: Handok Pharmaceutical Industry Co., Ltd., 1972).

Huang Yong-yuan, “The Unrevealed Aspects of Korean Medicine Physicians' Organization-Reconsidering over Research Society of the East and West Medicine," Salim 史林 59 (2017).

Huang Yong-yuan, "Traditional Korean Medicine Doctors and the Colonial Modernity of Traditional Korean Medicine during the Japanese Colonial Period,” Ph. D. diss., Korea University, 2018.

Institute for History of Medicine, Yonsei University ed., The Modernization of Korean Traditional Medicine during the Colonial Period 한의학 식민지를 않다: 식민지 
HUANG Yong-yuan : "Medicine of the Grassroots" : Korean Herbal Medicine Industry and Consumption during the Japanese Colonial Period

시기 한의학의 근대화 연구 (Seoul: Acane, 2008).

Institute of Urban Architecture, Department of Architectural Engineering, Korea University of Technology and Education ed., Data-based Survey Report on Korean Herbal Stores in Ganggyeong Jungang-ri and the Old Namil-dang 강경 종앙리 구 남일당 한약방 기록화 조사 보고서 (Cultural Heritage Administration, 2013).

Jung Byung-wook, "Colonial Rural Youth and Korean Ethnic Community in Japan: Based on the Investigation of Haman-gun, Gyeongsangnam-do Zhou's Diary (1933)。植民地農村靑年と在日朝鮮人社會-慶向南道咸安郡、周氏の日記(1933)の檢 討-,” Modernity in Diaries: Studies on Korea, Japan, and Germany 日記が語る 近代: 韓国・日本・ドイツの共同研究 (Kyoto: The Institute of Korean Studies at Doshisha University 同志社コリア研究センター, 2014).

Kim Nam-il, "The Academic Trend of Oriental Medicine during the Japanese Colonial Period as Observed through the Publication of Medical Books," Korean Journal of Medical History 의사학 15-1 (2006).

Kim Nam-il, Historical Records of Modern and Contemporary Traditional Korean Medicine 근현대 한의학 인물실록 (Seoul: Dulnyouk Publishing House, 2011).

Kim Taek-jong, "The 1918 Influenza Pandemic and Japanese Government-General of Korea's Preventive Measures against Epidemics,” Seoul National University, Journal of Humanities 인문과학논총 74-1 (2017).

Kim Tae-woo, "Modern Changes in Medicine in the Colonial Joseon: The Institution of Medical Apprentices in the Contexts of the Colonial Health Care System in an East Asian Nation-State," Korean Journal of the Social History of Medicine and Health 의료사회사연구 2 (2018).

Kwon Byeong-tak, A Study of Herbal Medicine Market 藥令市研究 (Seoul: Institute of Korean Studies, 1986).

Lee Geod-me, "A Study on the General Public Understanding and Utilization of Korean Traditional Medicine in the Colonial Period," Korean Journal of Medical History 의사학 15-2 (2006).

Medical Bureau of the Ministry of Health and Welfare 厚生省医務局, Japanese Medical History 医制百年史 (Tokyo: Medical Bureau of the Ministry of Health and Welfare, 1976).

Oh Chae-kun, “A Traditional Medicine Doctor, Gwangin Kim’s Battle against Jaundice 
HUANG Yong-yuan : "Medicine of the Grassroots" : Korean Herbal Medicine Industry and Consumption during the Japanese Colonial Period

during the Japanese Colonial Period," Korean Journal of Medical History 의사 학 28-2 (2019).

Pan Guijuan 潘桂娟 and Fan Zhenglun 爿正伦, Japanese Oriental Medicine 日本汉方医 学 (Beijing: China Press of Traditional Chinese Medicine, 1994).

Park Chan-young, "The Process and Change of Traditional Herbal Medicine Market Being Included in Colonial Trade Structure-With Daegu at the Center 전통 약령 시의 식민지 무역구조 편입과 변화-대구 약령시를 중심으로," The Transformation of Modern and Contemporary Eastern Asian Confucian Traditions and the Reorganization of Regional Communities 근현대동아시아 유학전통의 변용과 지 역공동체의 재편 (A Collection of 2017 International Academic Conference of the Institute of Korean Classical Studies, Jeonju University 전주대학교 한국고 전학연구소 2017년 국제학술대회 논문집).

Park Chan-young, "A study on Medicine Control Policy and Korean Medicine Merchant's Response under the Japanese Colonial Rule (1906-1938),” Master's diss., Kyungpook National University, 2019.

Park Gyeong-yong, Collection I of the Oral Data of Traditional Medicine-The Medical Job and Life of 6 Senior Practitioners of Korean Herbal Medicine Industry in Daegu Drug Market 전통의료 구술자료 집성 ( I ) -대구약령시 원로 한의약업인 6인의 의약업과 삶- (Gyeongin Publishing House, 2011).

Park Ji-hyeon, “Uisaeng (醫生) Activities of Confucian Intellectual Haeak (海岳) Kim Gwang-Jin (金光鎮) and their Meanings-The Identity and Medical Culture of Uisaeng during the Colonial Period," The Korean Historical Review 역사학보 229 (2016).

Park Yun-jae, “Japan's Oriental Medicine Policy in Colonial Korea," Korean Journal of Medical History 의사학 17-1 (2008).

Park Yun-jae, "Emergence of Large Pharmacies and Changes in Herb Medicine around 1900s Korea," Quarterly review of Korean history 역사와 현실 90 (2013).

Shin Chang-geon, "Medicine as Right against Might-Focusing on the Controversy over Eastern and Western Medicine in Mid-1930s Korea,” Shisō思想 905 (1999).

Shin Chang-geon, "Institutionalization of Research on Traditional Medicine in Keijo Imperial University," Society and History 사회와 역사 76 (2007).

Shin Dong-won, "The Formation of the Colonial Policy of Medical Care-Focused on 
the Policy of Korean Traditional Medicine," Han'guk Munhwa: Korean Culture 韓國文化 30 (2002).

Shin Dong-won, "Traditional Medicine under Japanese Rule after the 1930s," Korean Journal of Medical History 의사학 12-2 (2003).

Shin Jong-wan, "A Study on the Abolition of the Oriental Medical System According to the Japanese Invasion,” Master's diss., Kyung Hee University, 1990.

Soyoung Suh, Naming the Local: Medicine, Language and Identity in Korea since the Fifteenth Century (Cambridge \& London: Harvard University Press, 2017).

Tonomura Masaru 外村大, Historical Studies on Korean Ethnic Community in Japan: Formation, Structure and Change 在日朝鮮人社会の歷史学的研究: 形成 ·構造 · 变容 (Tokyo: Riyokuin Shobo 綠蔭書房, 2004).

Yang Jeong-pil, "Medicine Environment and Adaptation of Korean Trader for Medicinal Herbs from the Late 19th Century to the Early 20th Century," Korean Journal of Medical History 의사학 15-2 (2006).

Yang Jeong-pil, "White Ginseng Commercialization and Sales Expansion Activities of Gaesong Merchants in the 1910s and 1920s," Korean Journal of Medical History 의사학 20-1 (2011).

Yang Jeong-pil, "Commercial Traditions and Capital Accumulation of Modern Gaesong Merchants,” Ph. D. diss., Yonsei University, 2012.

Yang Jeong-pil, “A Study on Geumsan ginseng during Early Modern and Colonial Periods of Korea," The Journal for the Studies of Korean History 한국사학보 51 (2013).

Korean History Database, http://db. history.go. kr

Center for Korean Studies Material, http://archive.aks. ac. kr 


\section{"Medicine of the Grassroots": Korean Herbal Medicine Industry and Consumption during the Japanese Colonial Period}

HUANG Yong-yuan*

There is no doubt that the colonial period was a critical time for the establishment and expansion of modern Western medicine in Korea. However, did this act as a catalyst for the overall decline of traditional Korean medicine? While previous studies mainly focus on research based on the concept of Uisaeng (traditional Korean medicine doctor) and the medical policies implemented by the Japanese Government-General of Korea, this paper begins with the Korean herbal medicine industry, and comprehensively investigates the distribution and consumption of Korean herbal medicines during the colonial period from three perspectives: the policies for Korean medicine merchants implemented by the Japanese Government-General of Korea, changes in the Korean herbal medicine

\footnotetext{
* Assistant Professor, Korean Department \& Center for East Asian Studies, Sun Yat-sen University, China / E-mail: ahuang412@sina.com
}

Received: Jan. 31, 2020; Reviewed: Feb. 28, 2020; Accepted: Apr. 09, 2020 
HUANG Yong-yuan : "Medicine of the Grassroots" : Korean Herbal Medicine Industry and Consumption during the Japanese Colonial Period

industry, and consumption of Korean herbal medicines in the Korean society.

The colonial authorities' intention was to foster the advancement of Western medicine and phase out traditional Korean medicine. However, they merely imposed limitations on Uisaengs' operations-this policy loophole objectively left a window for Korean medicine merchants. Moreover, against the backdrop of the growing popularity of Western medicine and restrictions on the development of traditional Korean medicine by colonial authorities, the Korean herbal medicine industry, as one of the few "national industries" dominated by and serving Koreans, showed its tenacious vitality during that time. Korean medicine merchants responded to market changes with ease. They built different drugstores, such as traditional herbal stores mainly selling traditional Korean medicines, hybrid drugstores that simultaneously dealt with the manufacture and sale of patent medicines, and ginseng drugstores that specialized in the ginseng business. This classification promoted the commercialization of traditional Korean herbal medicine.

Another crucial condition for the vitality of the Korean herbal medicine industry is Koreans' preference for traditional Korean medicine. It is an indisputable fact that Western medicine gradually became popular and was recognized by the common man during the colonial period; nonetheless, Eastern medicine and Western medicine were not playing a zero-sum game. Through comprehensive macro and micro analysis, this paper demonstrates that, during the colonial period, when old and new ideas interacted, most Koreans, including upper-class elites and intellectuals who were open-minded about emerging concepts and options and had ample opportunities to avail western medical treatment, 
HUANG Yong-yuan : "Medicine of the Grassroots" : Korean Herbal Medicine Industry and Consumption during the Japanese Colonial Period

preferred traditional Korean medicine. Using Korean herbal medicines for illnesses remained the primary choice, While Western medicine assumed the role of a supplement to traditional treatment. This paper argues that the first reason for this phenomenon is the inertia of tradition, and the second is that Western medicine was not necessarily more effective than Korean herbal medicine at that time.

Specifically, it can be considered that, during the colonial period, the growing popularity of Western medicine failed to bring about a radical change in Koreans' regular medical interventions. Simultaneously, the Korean herbal medicine industry, one of the pillars offering medical support to the common man, adapted suitably while relying on the inertia of its own tradition. The industry's vitality and dynamism during the colonial period certainly underscore the need to amend the one-sided narrative of medical modernization vis-à-vis Western medicine.

Keywords: Korean Herbal Medicine; Korean Herbal Medicine Industry; Traditional Korean Medicine; Korean Medicine Merchant; Chosun; Japanese Colonial Period; Consumption; Tradition; Medical Modernization 